九州大学学術情報リポジトリ

Kyushu University Institutional Repository

\title{
Distribution of polycystine Radiolaria,
} Phaeodaria and Acantharia in the Kuroshio Current off Shikoku Island and Tosa Bay during Cruise KT07-19 in August 2007

Onodera, Jonaotaro

Research Institute for Global Change, Japan Agency for Marine Earth Science and Technology

Okazaki, Yusuke

Research Institute for Global Change, Japan Agency for Marine Earth Science and Technology

Takahashi, Kozo

Department of Earth and Planetary Sciences, Graduate of Science, Kyushu University

Okamura, Ke i

Center for Advanced Marine Core Research, Kochi University

他

https://doi.org/10.5109/19196

出版情報: 九州大学大学院理学研究院紀要 : Series D, Earth and planetary sciences. 32 (3)， pp.39-61, 2011-03-10. Faculty of Science, Kyushu University

バージョン :

権利関係 : 
Mem. Fac. Sci., Kyushu Univ., Ser. D, Earth \& Planet. Sci., Vol. XXXII, No. 3, pp. 39-61, March 10, 2011

\title{
Distribution of polycystine Radiolaria, Phaeodaria and Acantharia in the Kuroshio Current off Shikoku Island and Tosa Bay during Cruise KT07-19 in August 2007
}

\author{
Jonaotaro Onodera*, Yusuke Okazaki", Kozo Takahashi* ${ }^{* *}$ Kei Okamura ${ }^{* * *}$, and Masafumi Murayama***
}

\begin{abstract}
The occurrences of polycystine Radiolaria, Phaeodaria, and Acantharia are reported from plankton net samples, which were obtained in the transect covering from the Kuroshio Current off Shikoku Island to Tosa Bay during Cruise KT07-19 in August 2007. We employed $100 \mu \mathrm{m}$ as the mesh size of the plankton nets, which was coarser than the mesh size of many recent radiolarian studies (e.g., 44 or $63 \mu \mathrm{m}$ ). The obtained specimens in the samples were categorized into 130 polycystine radiolarian, and 17 phaeodarian, and 3 acantharian taxa. The marked similarity of the polycystine radiolarian assemblages encountered in this study to those reported from the tropical and subtropical oceans in the literature clearly indicates the significant influence by the warm Kuroshio Current. Furthermore, the observed polycystine radiolarian assemblages are similar to those of the previous result from the same specific study area. However, the vertical distribution patterns of some of the major polycystine radiolarian and phaeodarian taxa are different from the previous results from the same region. The differences in vertical distribution may be primarily due to the differences in vertical water mass conditions due to different sampling seasons. In spite of the lengthy sample storage for seven months after the sampling in the shore laboratory, many acantharian specimens were still preserved and encountered in the laboratory census, representing the acantharian presence in the summer sea surface waters in the Kuroshio Current area.
\end{abstract}

Keywords: Radiolaria, Phaeodaria, Acantharia, Kuroshio, MTD-net, subtropical assemblage

\section{Introduction}

In the subtropical oceans Radiolaria normally represent one of the major biosiliceous planktonic particles (e.g., Boltovskoy et al., 2010; Ishitani and Takahashi, 2007). In addition to calcareous microplankton particles, together with diatoms the siliceous skeletons of Radiolaria and Phaeodaria significantly contribute as the ballast of sinking particles to the vertical transport of organic material to the interior of the deep oceans (Honjo et al., 2008). Thus, it is important to study them in detail. However, the information concerning the distributio of Radiolaria and related groups in the water column is still meager and hence further studies are warranted. Phaeodaria had been traditionally considered as one group of Radiolaria (see discussion in Takahashi and Anderson, 2002) whereas it has recently been often treated as one of Cercozoa (Poulet et al., 2004). As the taxonomy of polycystine Radiolaria, Class Polycystinea is one of the representative groups in Subphylum Radiolaria (Müller) Cavalier-Smith 1993. Class Polycystinea is subdivided into two Orders: Spumellaria Ehrenberg 1875 and Nassellaria Ehrenberg 1875 (Anderson et al., 2002). Class Acantharia, which is classified into Radiolaria with recent substantial molecular support, was traditionally treated separately from Radiolaria. This is because that they bear celestite $\left(\mathrm{SrSO}_{4}\right)$ skeletons, which are different from polycystine Radiolaria with biogenic opal skeletons. Although there have been many studies on polycystine Radiolaria, works concerning

Manuscript received on 1 Dember 2010; accepted on 20 January 2011

* Research Institute for Global Change, Japan Agency for Marine Earth Science and Technology, Natsushima-cho 2-15, Yokosuka, 237-0061, JAPAN; Corresponding author's e-mail: onoderaj@jamstec.go.jp

** Department of Earth and Planetary Sciences, Graduate School of Science, Kyushu University, Hakozaki6-10-1, Fukuoka, 812-8581, JAPAN

*** Center for Advanced Marine Core Research, Kochi University, B200 Monobe, Nankoku, 783-8502, JAPAN 
Acantharia are quite limited due to readily dissolved nature of their celestite skeletons. However, in the viewpoint of geochemical cycle, acantharian production in the subtropical oceans may significantly influence, for instance, the distribution of $\mathrm{Sr} / \mathrm{Ca}$ ratios in the upper water column (De Deckker, 2004). Based on the microscopic examinations on plankton tow and surficial bottom sediment samples we report the distribution of polycystine Radiolaria, Phaeodaria and Acantharia in this paper in order to serve a basis for the future studies.

\section{Materials and Methods}

\subsection{Study Materials}

The study area is located off Shikoku Island and Tosa Bay in the western North Pacific (Fig. 1). While this is in the temperate region with northern latitude of the Tropic of Cancer the watermasses here are largely influencd by the northernly flow of the Kuroship Current and hence this region is conceptually close to the subtropics. The studied materials were obtained at six sites during Cruise KT07-19 on board R/V Tansei-Maru of Japan Agency for Marine Earth Science and Technology (JAMSTEC), which took place during 8-10 August 2007 (Table 1; Fig. 1). One of the two microplankton sampling methods was proceeded, employing a standard twin North Pacific net (NORPAC net: Motoda, 1957), at Sites M1, M2, and M3. The other sampling method employed involves Motoda horizontal nets (MTD plankton net; lateral tow: Motoda, 1971); the plankton tow samples were obtained from seven discrete depth layers at Sites M5, M7, and M9. During the lateral towing of the MTD plankton nets for a half an hour, the ship speed was controlled ( $\sim 2 \mathrm{knot})$ in order to keep the wire angle of $45^{\circ}$. The applied mesh size of the plankton nets for the both moethods is $100 \mu \mathrm{m}$ because of the primary objective in foraminifer sampling. The obtained plankton samples were immediately fixed by $5 \%$ sample volume of buffered ( $\mathrm{pH} 7.8$ ) formaldehyde with sodium tetraborate. The rose bengal stain was added to the MTD samples in order to distinguish live specimens (stained) from dead specimens (stain-free). The twin NORPAC net was towed without a flow meter

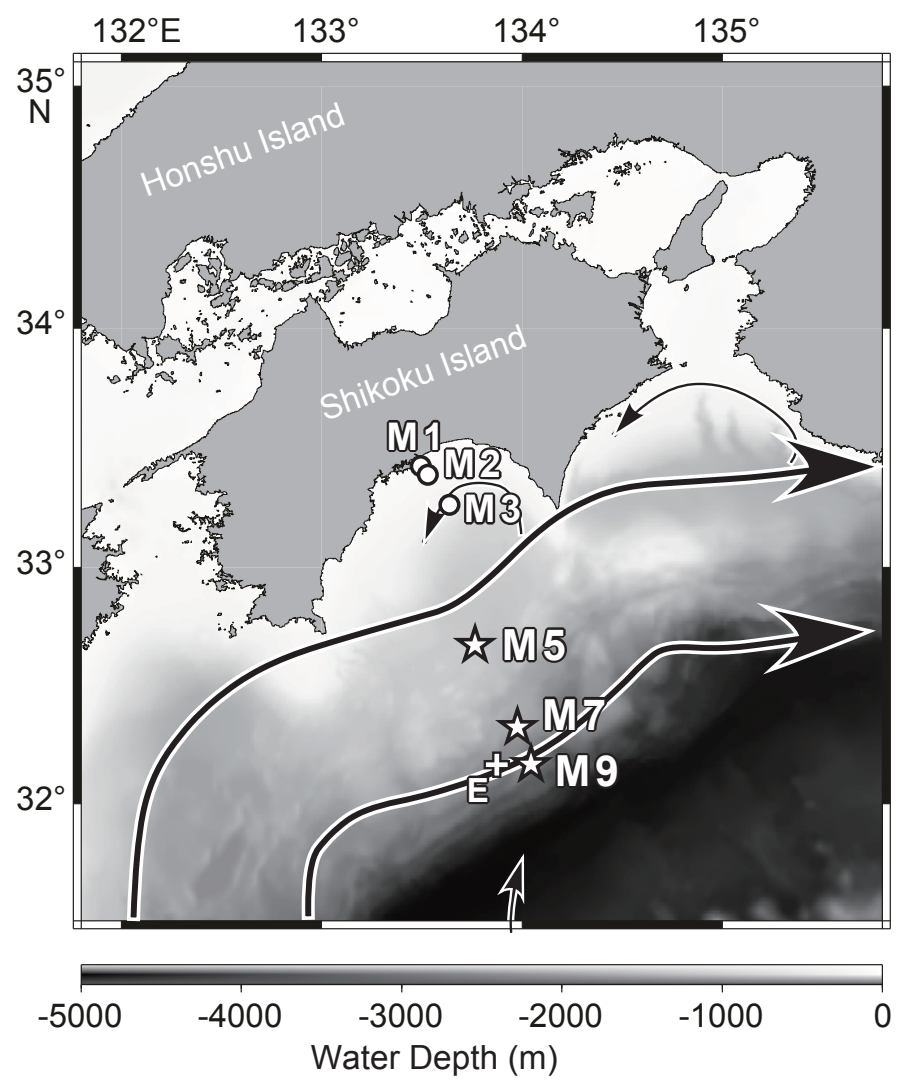

Fig. 1. Map of the studied area configured with GMT. The symbol with circles represents the sampling locations for the vertical towing. The symbol with stars represents the locations for the lateral towing (MTD) and surface sediment sampling. The symbol with a cross is the location where Station E was occupied in a previous study (Ishitani and Takahashi, 2007). Two bold arrows designate the northern and southern boundaries of the Kuroshio Current on 7 August 2007, among the arrows representing the estimated lines of sea surface stream, (JHOD, JCG, 2007). 
attached. Furthermore, a flow meter test for the MTD net could not be conducted due to the limited ship time. Therefore, reliable standing stocks cannot be estimated in this study. The results of specimen counts are shown as relative abundance in total numbers of encountered polycystine radiolarian, phaeodarian and acantharian specimens. Unexpected small number of live sea surface and subsurface dwellers were observed in deep MTD samples. Such rare occurrences are considered as the result of contamination in the upper water column during the cast of the net from sea surface to the deep depth. Therefore, some sampling error is included in the obtained $\%$ data in deep MTD samples.

Table 1. Summary for microzooplankton and microfossil samples obtained during Cruise KT07-19 of $\mathrm{R} / \mathrm{V}$ Tansei-maru.

\begin{tabular}{|c|c|c|c|c|c|c|c|}
\hline Site ID & Coordinate & $\begin{array}{c}\text { Start Date } \\
\text { and Time } \\
\text { (yr/m/d, JST) }\end{array}$ & $\begin{array}{l}\text { Water } \\
\text { Depth } \\
(\mathrm{m})\end{array}$ & Sample Type & $\begin{array}{l}\text { Towing } \\
\text { Speed }\end{array}$ & $\begin{array}{l}\text { Target } \\
\text { Depth } \\
(\mathrm{m})\end{array}$ & $\begin{array}{l}\text { Flow } \\
\text { Meter } \\
\text { Read }\end{array}$ \\
\hline M1 & $\begin{array}{l}33^{\circ} 26^{\prime} \mathrm{N} \\
133^{\circ} 30^{\prime} \mathrm{E}\end{array}$ & 2007/8/8 9:40 & 31 & $\begin{array}{l}\text { Twin NORPAC } \\
\text { (mesh: } 100 \mu \mathrm{m})\end{array}$ & $0.5 \mathrm{~m} / \mathrm{s}$ & $0-20$ & --- \\
\hline M2 & $\begin{array}{l}33^{\circ} 24^{\prime} \mathrm{N} \\
133^{\circ} 32^{\prime} \mathrm{E}\end{array}$ & 2007/8/8 7:20 & 70 & $\begin{array}{l}\text { Twin NORPAC } \\
\text { (mesh: } 100 \mu \mathrm{m})\end{array}$ & $0.5 \mathrm{~m} / \mathrm{s}$ & $0-50$ & --- \\
\hline M3 & $\begin{array}{c}33^{\circ} 14^{\prime} \mathrm{N} \\
133^{\circ} 38^{\prime} \mathrm{E}\end{array}$ & 2007/8/10 5:10 & 231 & $\begin{array}{l}\text { Twin NORPAC } \\
\text { (mesh: } 100 \mu \mathrm{m})\end{array}$ & $0.5 \mathrm{~m} / \mathrm{s}$ & $0-50$ & --- \\
\hline M5 & $\begin{array}{l}32^{\circ} 40^{\prime} \mathrm{N} \\
133^{\circ} 46^{\prime} \mathrm{E}\end{array}$ & 2007/8/8 21:30 & 990 & $\begin{array}{l}\text { Closing MTD + } \\
\text { open net at } 0 \mathrm{~m} \\
\text { (mesh: } 100 \mu \mathrm{m}) \text {; } \\
\text { surface sediment } \\
\text { by Multiple Core } \\
\text { sampler (MC) }\end{array}$ & 2 knot & $\begin{array}{r}0 \\
50 \\
100 \\
200 \\
300 \\
500 \\
750\end{array}$ & $\begin{array}{c}2869 \\
4345 \\
442 \text { a } \\
14475 \\
3522 \text { a } \\
21460 \\
24280\end{array}$ \\
\hline M7 & $\begin{array}{l}32^{\circ} 20^{\prime} \mathrm{N} \\
134^{\circ} 00^{\prime} \mathrm{E}\end{array}$ & 2007/8/9 13:55 & 1935 & $\begin{array}{c}\text { Closing MTD + } \\
\text { open net at 0m } \\
\text { (mesh: } 100 \mu \mathrm{m}) \text {; } \\
\text { MC }\end{array}$ & 2 knot & $\begin{array}{r}0 \\
50 \\
100 \\
200 \\
300 \\
500 \\
1000\end{array}$ & $\begin{array}{r}4162 \\
7522 \text { b } \\
17513 \\
13038 \\
28240 \\
245 \\
3395\end{array}$ \\
\hline M9 & $\begin{array}{l}33^{\circ} 09^{\prime} \mathrm{N} \\
134^{\circ} 03^{\prime} \mathrm{E}\end{array}$ & 2007/8/9 22:00 & 2750 & $\begin{array}{c}\text { Closing MTD + } \\
\text { open net at 0m } \\
\text { (mesh: } 100 \mu \mathrm{m}) \text {; } \\
\text { MC }\end{array}$ & 2 knot & $\begin{array}{r}0 \\
50 \\
100 \\
200 \\
300 \\
500 \\
750\end{array}$ & $\begin{array}{r}4501 \\
7045 \\
369 \\
919 \\
1482 \\
732 \mathrm{a} \\
5611 \mathrm{~b}\end{array}$ \\
\hline
\end{tabular}

${ }^{a}$ : plankton net tangled during towing; ${ }^{b}$ : plankton net mesh was torn during towing

The obtained samples had been kept in a refrigerator $\left(4^{\circ} \mathrm{C}\right)$ in a shore laboratory. All of the sample treatment for this study was conducted in March 2008, seven months after the collection at sea. Portions of samples were sieved through stainless screens of 1000,500 , and $63 \mu \mathrm{m}$ mesh size, respectively. The residue on these mesh sizes was filtered onto a membrane filter (with $3 \mathrm{~mm}$ grid printed) and desalted. The filter was dried in an oven at $40^{\circ} \mathrm{C}$ and the sample was mounted on a glass slide with Canada Balsam ${ }^{\mathrm{R}}$. In order to observe skeletons of polycystine Radiolaria and Phaeodaria employing a field emission scanning electron microscope (FE-SEM), portions of plankton net samples and surface sediments taken by multiple core sampler (MC) were treated with hydrogen peroxide and sodium hexametaphosphate. The skeletal counts were proceeded under a light microscope (LM) to distinguish the live/dead status of each of the specimens. The polycystine radiolarian and phaeodarian skeletons were normally identified at genus or family level based on the illustrations published by Boltovskoy and Riedel (1987) and Takahashi (1991). Concerning the encountered living specimens of a radiolarian Sphaerozoum, both numbers of their spicules and protoplasm were counted (Table 2). 


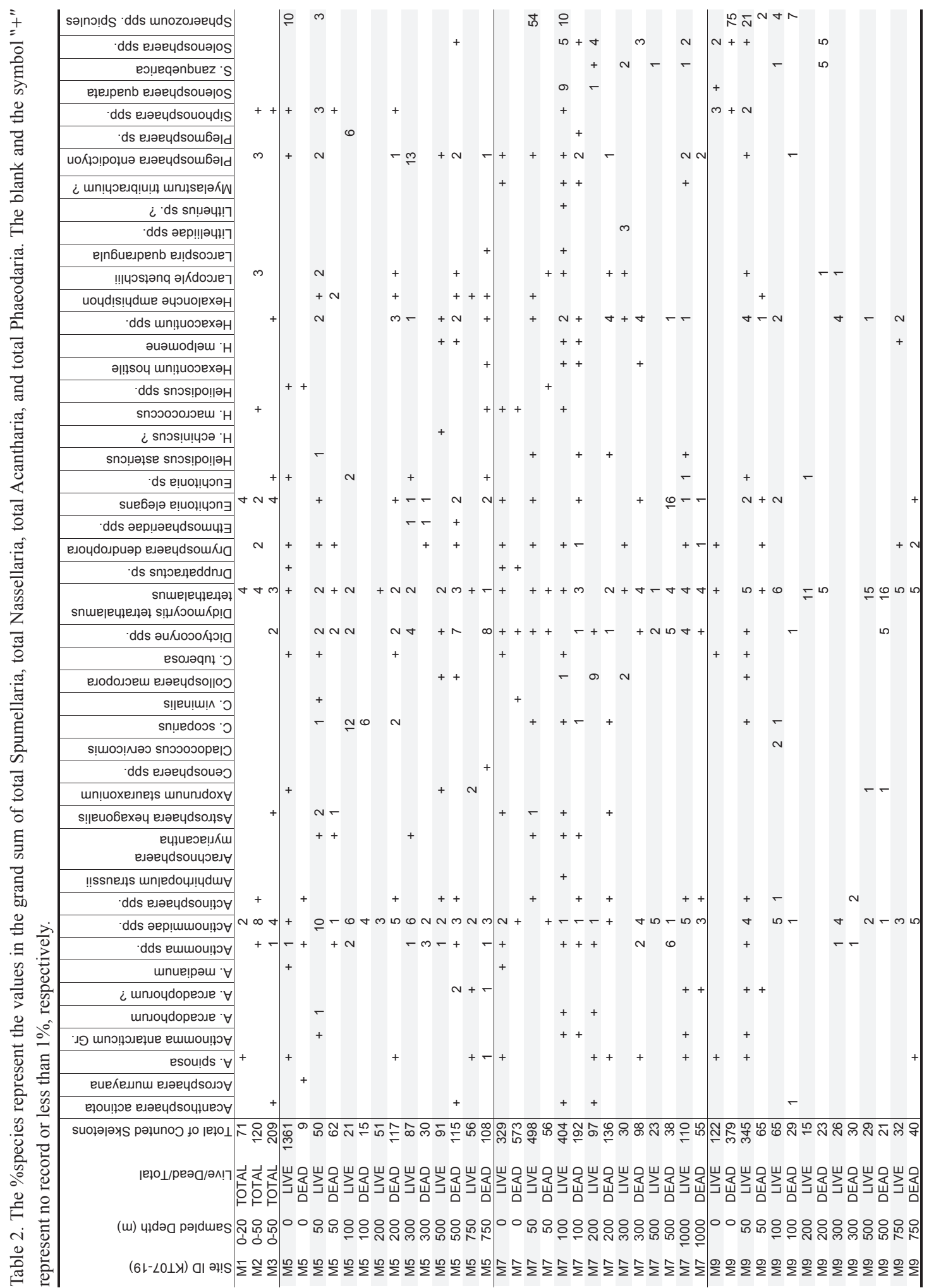




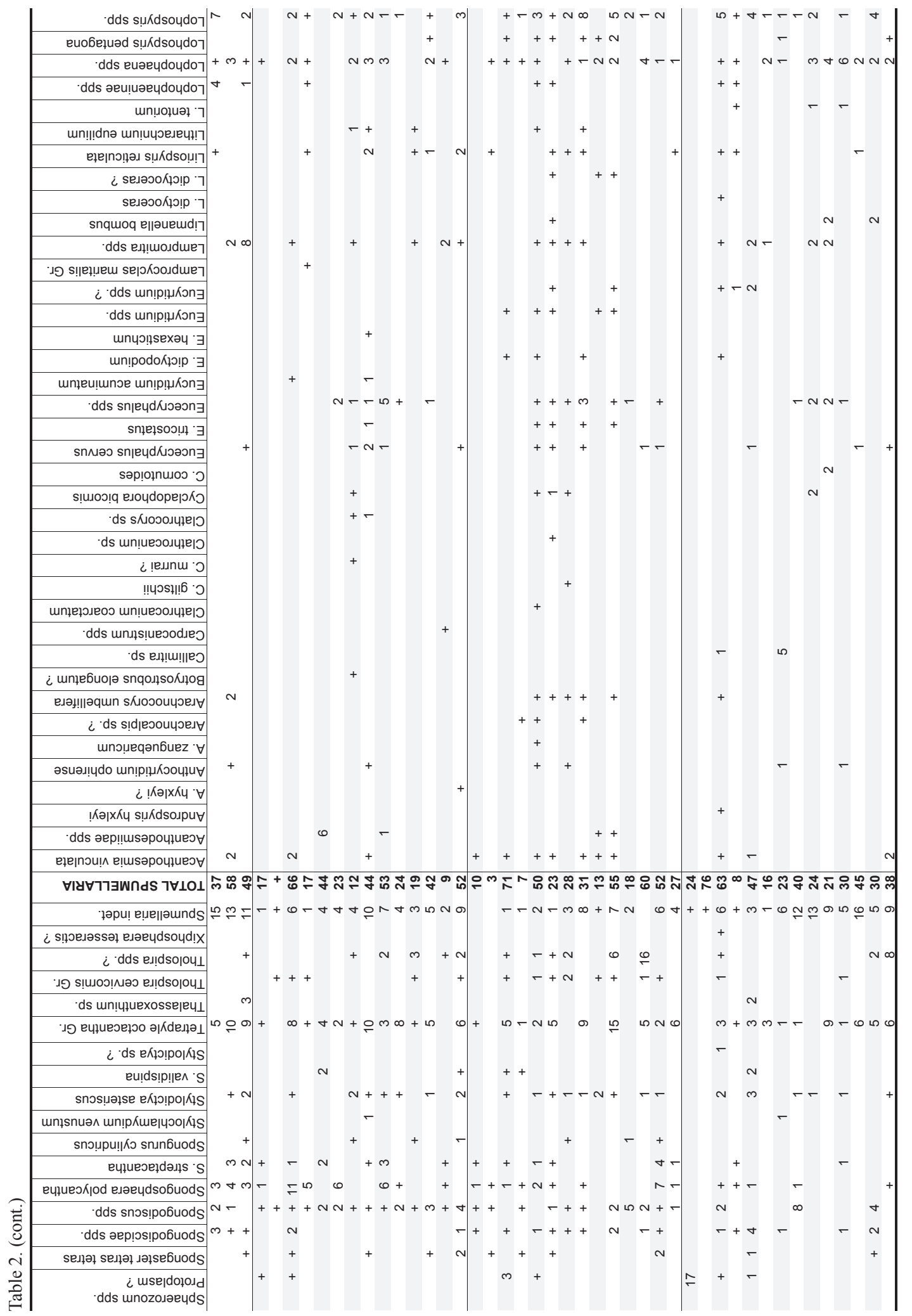




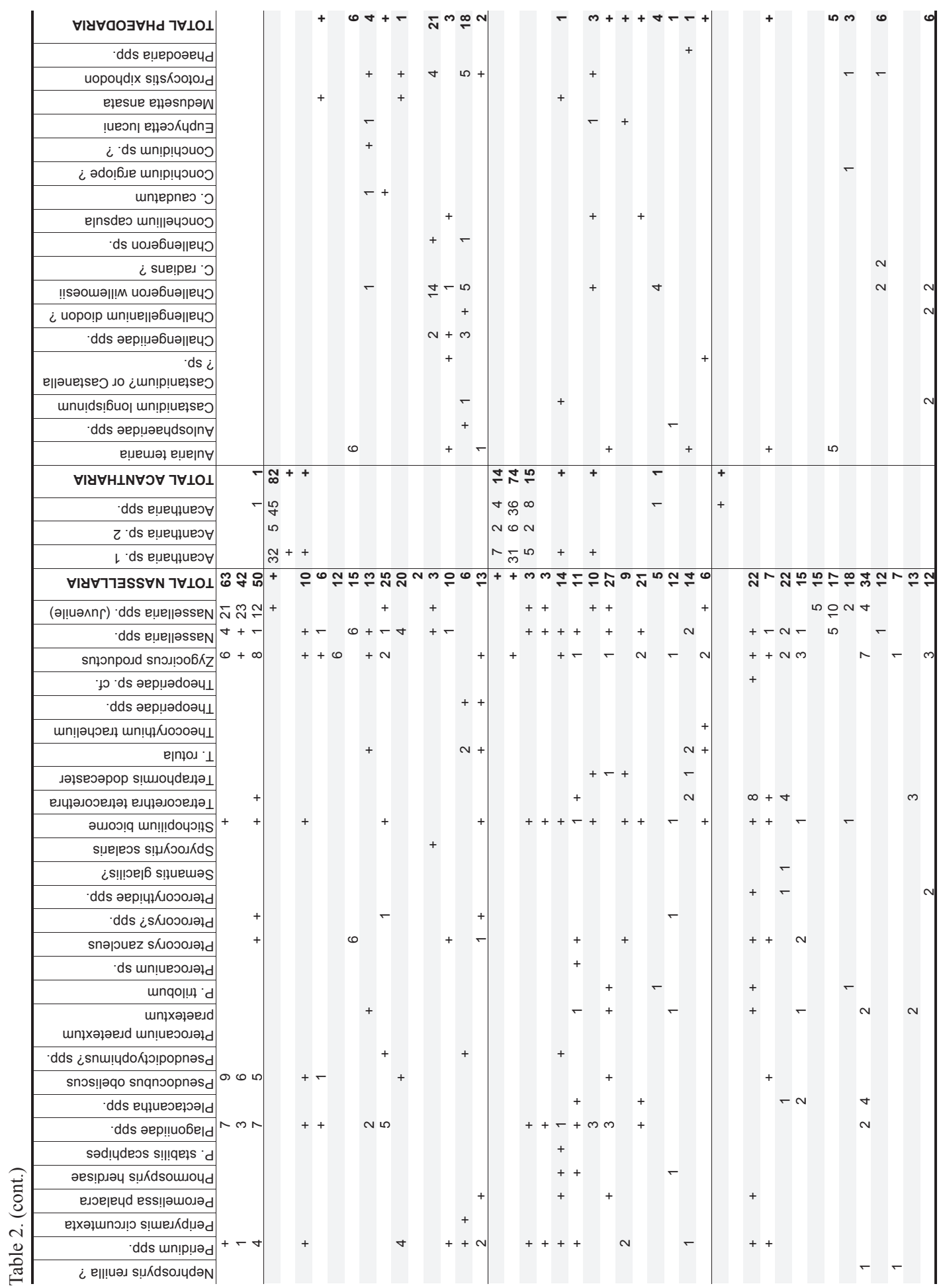




\section{Results and Discussion}

\subsection{Oceanographic conditions}

Sea surface temperatures ranged from $25.3^{\circ} \mathrm{C}$ (Site M1) to $29.4^{\circ} \mathrm{C}(\mathrm{M} 7)$. According to the daily report on the Kuroshio Current provided by Japan Coast Guard, Site M5 on $7^{\text {th }}$ August 2007 was located in the central part of the Kuroshio Current (Fig. 1). Site M7 was located in the southern part of the Kuroshio Current. While the southern edge of the Kuroshio Current was unclear, Site M9 appeared to be out side of the Kuroshio Current based on the on-site CTD vertical profiles. Water temperature became colder with increased water depth. Below $200 \mathrm{~m}$ the isotherm depth shoaled from Site M9 towards Site M5. Sea surface salinity was the lowest at Site M1 (33.1 psu) and the highest at Site M9 (34.5 psu). The high salinity waters ( $>34.5 \mathrm{psu})$ in the subsurface at Sites M5-M9 reflect the lateral advection of the central subtropical waters. The maximum of chlorophyll concentration was observed around the pycnocline depth at each site. In the plankton tow samples at Site M2, a diatom Coscinodiscus sp. was dominant and conspicuous in the net phytoplankton $(>100 \mu \mathrm{m})$.

\subsection{Polycystine Radiolaria}

Among the observed microzooplankton groups, polycystine Radiolaria represented the major component in all the samples except for the sea surface at Sites M5 and M7 (Fig. 2). The encountered polycystine radiolarian specimens in all the sample slides were categorized into the following two orders (Anderson et al., 2002): Spumellaria: 64 taxa; and Nassellaria 66 taxa (Table 2). While the sampled locations spans from $32.15^{\circ} \mathrm{N}$ to $33.43^{\circ} \mathrm{N}$, which are within the temperate climatic region of the world, the obtained polycystine radiolarian

(a) St. M1

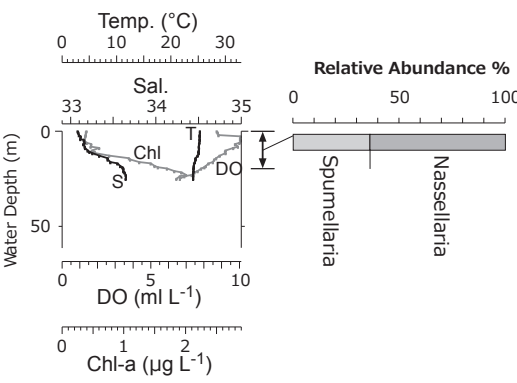

(b) St. M2

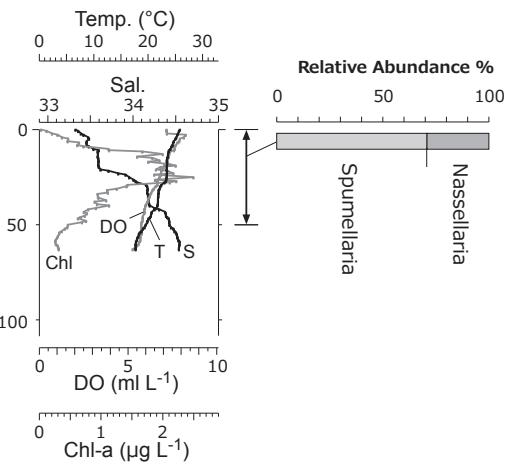

(c) St. M3

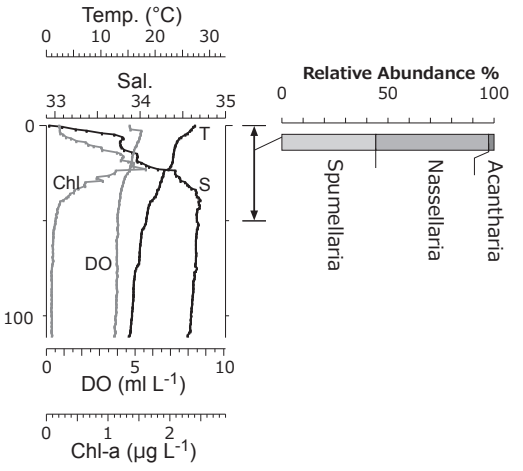

(d) St. M5

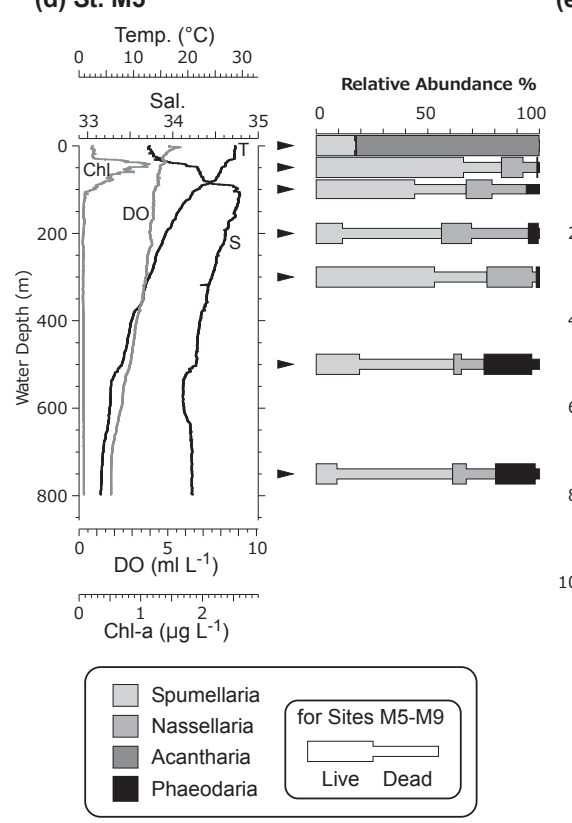

(e) St. M7

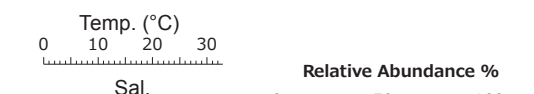

(f) St. M9

.


assemblages clearly show the affinity to the subtropic to the tropic assemblages. This is due to the influence of the Kuroshio Current, which laterally advects the warm subtropical water mass from the lower latitudes along the western boundary of the North Pacific. The major encountered taxa in this study are essentially the same as those reported in the previous study at Station E in June 2002 (Fig. 1; Ishitani and Takahashi, 2007). However,the vertical distribution of characteristic species indicated by Ishitani and Takahashi (2007) were different from the results in this study. The differences in the vertical distribution of polycystine Radiolaria are primarily due to the seasonal difference in water mass conditions in the upper water column.

The relative abundance of Order Spumellaria was usually at similar level or higher than that of Order Nassellaria. The spumellarian assemblages were represented by Didymocyrtis tetrathulumus, Tetrapyle octacantha group. Tetrapyle octacantha group and Didymocyrtis tetrathalamus; they commonly occur in the subtropical and tropical oceans (Kling, 1979; Yamashita et al., 2002; Boltovskoy et al., 2010). In addition to Family Collosphaeridae, abundant Spaherozoum spicules were the main cause of high \% Spumellaria in the shallow layers at Sites M5-M9. In particular, radiolarian assemblage at sea surface at Site M9 was characterized by the high abundance of Sphaerozoum with Siphonosphaera spp. and Solenosphaera spp., all of which belong to colonial radiolarians. Because that the colonial radiolarians prosper better in the pelagic waters than in more eutrophic waters the result shown here are conformable with the known distribution (Takahashi et al., 1995). Interestingly, Tetrapyle octacantha group and Didymocyrtis tetrathalamus, which commonly occur in the subtropical and tropical oceans (Kling, 1979; Yamashita et al., 2002; Boltovskoy et al., 2010), were commonly observed in many samples. Living Dictyocoryne spp. were observed in many samples at Sites M5 and M7 whereas the living specimens of this taxon were encountered only at $50 \mathrm{~m}$ at Site M9.

The vertical trend of \%Nassellaria at Sites M5-M9 shows the maximum depth at $200 \mathrm{~m}$ or $300 \mathrm{~m}$, which correspond to the lower part of high salinity layer (Fig. 2). The increase in \%Nassellaria from the surface layer to the deeper layer is the same characteristics as in the previous observation in the oligotrophic tropical ocean (Yamashita et al., 2002). Lophophaena spp. and Lophospyris spp. were found in many samples. The high abundance of these taxa were also reported in the subtropical and tropical oceans (Kling, 1979; Yamashita et al., 2002). The nassellarian assemblage at Sites M1-M3 was mainly composed of Pseudocubus obeliscus, Zygocircus productus, Plagoniidae spp., and juvenile of Nassellaria spp. (Table 2). Psudocubus obeliscus and Z. productus were characteristically observed in the surface waters (Yamashita et al., 2002). The high abundances of P. obeliscus at coastal sites rather than pelagic sites appear to be related to the high primary productivity (Ishitani and Takahashi, 2007) and high nutrient supply in the equatorial upwelling (Yamashita et al., 2002). At Sites M5-M9, \%Nassellaria was significantly minor at the sea surface. There are two possible reasons for the minor $\%$ Nassellaria representations. The first reason is the relative dominance of Spaherozoum spicules or Acantharia. Another reason is the limited standing stock of Nassellaria at sea surface at Sites M5-M9; Nassellaria were absent at Site M9 or 4-5 specimens only at Sites M5 and M7 whereas the encountered Spumellaria were greater than 100 specimens except for Sphaerozoum spicules. In the deep layer at Site M5-M9, Eucecryphalus spp. were encountered.

\subsection{Phaeodaria}

Seventeen phaeodarian taxa were observed mainly below the depth of chlorophyll concentration maximum at Sites M5-M9 (Fig. 2). The relative abundance of total Phaeodaria in the studied microplankton groups was higher than that of total Nassellaria at $500 \mathrm{~m}$ and $750 \mathrm{~m}$ at Site M5. The major taxon at Site M5 was Challengeron willemoesii in addition to Protocystis xiphodon and Challengeriidae spp. (Table 2). The depths with abundant Challengeron willemoesii were deeper than the previous result in the equatorial Pacific (as subsurface dwellers in 120-200 m: Yamashita et al., 2002). While phaeodarian specimens at Site M2 were absent in the census sample slides (Table 2), few skeletons of Medusetta ansata were found in the treated sample for photomicrographs (Plate 13, fig. 1).

The relative increase of phaeodarian abundance with respect to polycystine radiolarians in the deep layers is common in the tropical oceans (Dworetzky and Morley, 1987; Yamashita et al., 2002). When the relatively high standing stocks of Phaeodaria relative to polycystine Radiolaria were observed in the subsurface layers (40-200 $\mathrm{m}$ ) around Japan, salinity and water temperature were about $34 \mathrm{psu}$ and $5-13^{\circ} \mathrm{C}$, according to the CTD profile figure in Ishitani and Takahashi (2007). Such values in salinity and water temperature were also observed in this study in the deep layers, which roughly correspond to the sampled depths with the observed living phaeodarian specimens (Fig. 2).

\subsection{Acantharia}

In spite of the fact that the studied samples had been stored in a refrigerator for seven months after sampling, 
common to dominant acantharian specimens were encountered in the samples from the sea surface and upper waters of Sites M5 and M7 (Fig. 2). The dominant acantharian taxon at Sites M5 and M7 was Holacanthida(?) sp. as shown in Plate 13, figs. 7 and 8. Most acantharian specimens at Site M5 had the stained protoplasm, suggesting living conditions at the time of sampling. However, many specimens at the sea surface at Site M7 were dead without protoplasm (Fig. 2). The acantharian occurrences were trace level at Sites M3 and M9 and absent at Sites M1 and M2.

In general, acantharian skeletons are readily dissolved after death (Beers and Stewart, 1970) because of the unsaturated strontium sulfate concentrations in sea waters. The high abundance of acantharians at Sites M5 and M7 are unusual. This is because that addition of strontium for the sake of skeletal preservation (Michaels, 1988) was not proceeded to the acquired samples, which were kept in the buffered formaldehyde solution. Although the strontium concentration in the waters of the plankton net samples has not yet been analyzed, we suspect that some portion of acantharian skeletons may have been dissolved prior to the point where strontium concentration became saturated in the stored samples. The skeletal abundance ratios of acantharian versus polycystine radiolarians at sea surface at Sites M5 and M7 were two orders of magnitude less than those in the previous results without significant acantharian skeleton dissolution (Beers et al., 1975 in the central North Pacific gyre; De Deckker, 2004 in Indian Ocean). Therefore, the relative abundance of acanthaians at Sites M5 and M7 may originally have been significantly higher than our obtained results.

Based on the biogeographic occurrence pattern in this study, the high abundance of acantharians can be related to the summer surface waters of the Kuroshio Current. According to De Deckker (2004), the acantharian assemblage in the Mediterranean Sea around Italy suggested an ecological relationship to salinity gradient (Bottazzi, 1978; Bottazzi and Andreoli, 1978). In this study, the $\sigma_{\mathrm{t}}$ values determined by both salinity and water temperature were lower than that in the Mediterranean data when acantharians dominated relative to polycystine radiolarians and phaeodarians. Sigma-t $\left(\sigma_{\mathrm{t}}\right)$ at $0 \mathrm{~m}$ at Sites M5 and M7 were 21.2 and 21.3, respectively, which were lower than $\sigma_{\mathrm{t}}$ at sea surface at nearshore Site M1 $\left(\sigma_{\mathrm{t}}=22.1\right)$ and offshore Site M9 $\left(\sigma_{\mathrm{t}}=22.1\right)$. Not only salinity difference but also higher water temperature appear be related to the biogeographic patterns of acantharian distribution in this study. However, at Site M3 with the lowest $\sigma_{t}$ at sea surface, \%Acantharia was minor (Fig. 2). Such a low \%Acantharia is explained by the difference in the sampling method (vertical towing for 0-50 $\mathrm{m}$ at Site M3). The previous study shows that the vertical distribution of acantharian abundance steeply decreases below $20 \mathrm{~m}$ water depth (Michaels, 1988). Therefore, the \%Acantharia in the vertical tow sample at Site M3 appears to be suppressed, with the view that the standing stock of polycystine radiolarians just below the sea surface was relatively abundant compared to the acantharian standing stock.

\section{Acknowledgements}

We thank the captain, crew, technical staff, and scientists on board R/V Tansei-Maru of JAMSTEC for their efforts in the CTD observations and plankton two sampling employed in this study. We are grateful to Dr. Yoshiyuki Ishitani at JAMSTEC who reviewed the manuscript of this paper for his critical and constructive comments, which were greatly helpful in revising the manuscript. This work was financially supported by the Kochi University President's Discretionary Grant in 2007 and 2008.

\section{References}

Anderson, O. R., Nigrini, C., Boltovskoy, D., Takahashi, K., and Swanberg, N. R. (2002) Class Polycystina. In: The Second Illustrated Guide to the Protozoa, Lee, J.J., Leedale, G.F., and Bradbury, P., (eds.), Society of Protozoologists, Lawrence, KS. 994-1022.

Beers, J. R., and Stewart, G. L. (1970) The preservation of acantharians in fixed plankton samples. Limnology and Oceanography, 15, 825-827.

Beers, J. R., Reid, F.M.H., and Stewart, G. L. (1975) Microplankton of the North Pacific Central Gyre. Population structure and abundance, June 1973. Internationale Revue Gesamtes Hydrobiologie, 60, 607-638.

Boltovskoy, D., and Riedel, W.R. (1987) Polycystine Radiolaria of the California Current region: seasonal and geographic patterns. Marine Micropaleontology, 12, 65-104.

Boltovskoy, D., Kling, S. A. Takahashi, K. and Bjørklund. K. (2010) World atlas of distribution of recent Polycystina (Radiolaria). Paleotologia Electronica, Article Number: 13.3.18A; http://palaeo-electronica. org/2010_3/215/index.html.

Bottazzi, E.M. (1978) Systematic-ecological aspects of Radiolaria with special reference to Acantharia. Bolletino 
Zoologica, 45, 133-144.

Bottazzi, E. M., and Andreoli, M.G. (1978) Distribuzione stagionale degli Acantari e dei Radiolari (Protozoa, Sarcodina) in diverse zone costiere dei mari italiani. L'Ateneo Parmense Acta Naturalia, 14, 477-500.

De Deckker, P. (2004) On the celestite-secreting Acantharia and their effect on seawater strontium to calcium ratios. Hydrobiologia, 517, 1-13.

Dworetzky, B.A., and Morley, J.J. (1987) Vertical distribution of radiolaria in the eastern Equatorial Atlantic: analysis of a multiple series of closely-spaced plankton tows. Marine Micropaleontology, 12, 1-19.

Honjo, S., Manganini, S.J., Krishfield, R.A., Francois,R. (2008) Particulate organic carbon fluxes to the ocean interior and factors controlling the biological pump: A synthesis of global sediment trap programs since 1983. Progress in Oceanography, 76, 217-285.

Ishitani, Y., and Takahashi, K. (2007) The vertical distribution of Radiolaria in the waters surrounding Japan. Marine Micropaleontology, 65, 113-136.

Kling, A.S. (1979) Vertical distribution of polycystine radiolarians in the central North Pacific. Marine Micropaleontology, 4, 295-318.

Michaels, A.F. (1988) Vertical distribution and abundance of Acantharia and their symbionts. Marine Biology, 97, 559-569.

Motoda, S. (1957) North Pacific standard plankton net. Information Bulletin on Planktology in Japan, 4, 13-15.

Motoda, S. (1971) Devices of simple plankton apparatus V. Bulletin of the Faculty of Fisheries Hokkaido University, 22, 101-106.

Poulet, S., Berney, C., Fahrni, J., and Pawlowski, J.A.N. (2004) Small-subunit ribosomal RNA gene sequences of Phaeodarea challenge the monophyly of Haeckel's Radiolaria. Protist, 155, 53-63.

Takahashi, K. (1991) Radiolaria: Flux, ecology, and taxonomy in the Pacific and Atlantic. In: Honjo, S. (Ed.), Ocean Biocoenosis Series, 3. Woods Hole Oceanography Inst. Press, Woods Hole, MA. pp. 303.

Takahashi, K., Oba, T., Yamazaki, H., and Ohkouchi, N. (1995) Paleoceanographic changes based on radiolarian fossils during the past $80 \mathrm{ky}$ in the western Tropical Pacific. Kaiyo Monthly, 27 (8), 466-473. [in Japanese with English fig. \& table captions.]

Takahashi, K., and Anderson, O. R. (2002) Class Phaeodaria. In: The Second Illustrated Guide to the Protozoa, Lee, J.J., Leedale, G.F., and Bradbury, P., (eds.), Society of Protozoologists, Lawrence, Kansas. 981-994.

Yamashita, H., Takahashi, K., and Fujitani, N. (2002) Zonal and vertical distribution of radiolarians in the western and central Equatorial Pacific in January 1999. Deep-Sea Research II, 49, 2823-2862. 
Plate 1
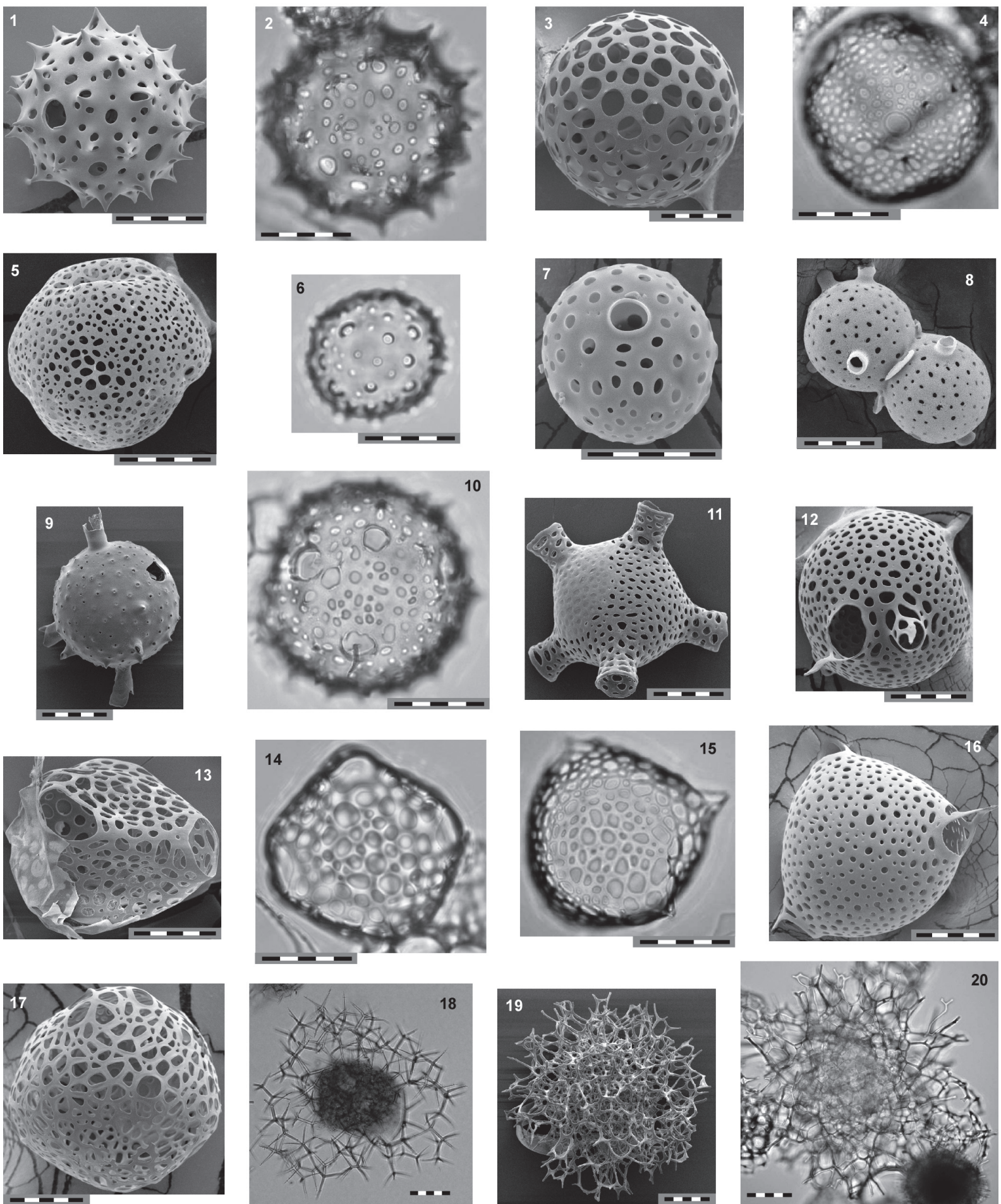

Plate 1. Spumellaria. All scale bars $=50 \mu \mathrm{m}$. The sample ID of each photomicrograph is represented in parenthesis. 1, 2. Acrosphaera spinosa, 3. Collosphaera macropora, 4, 5. Collosphaera tuberosa, 6-10. Siphonosphaera spp., 11. 12. Solenosphaera quadrata, 13, 14. Solenosphaera zanquebarica, 15-17. Solenosphaera spp., 18. Sphaerozoum sp., 19, 20. Plegmosphaera entodictyon (figs. 1-3, 5, 6, 10-12, 14-17, 19, 20.: Sample Site M9, Multiple Core Sample (MC), 0-1 cm; figs. 4, 7, 8.: M5, MC, 0-1 cm; 9. M9,: MTD net sample (MTD), 50 m; 13. M7, MTD, 50 m; fig. 18.: M9, MTD, 0 m) 
Plate 2
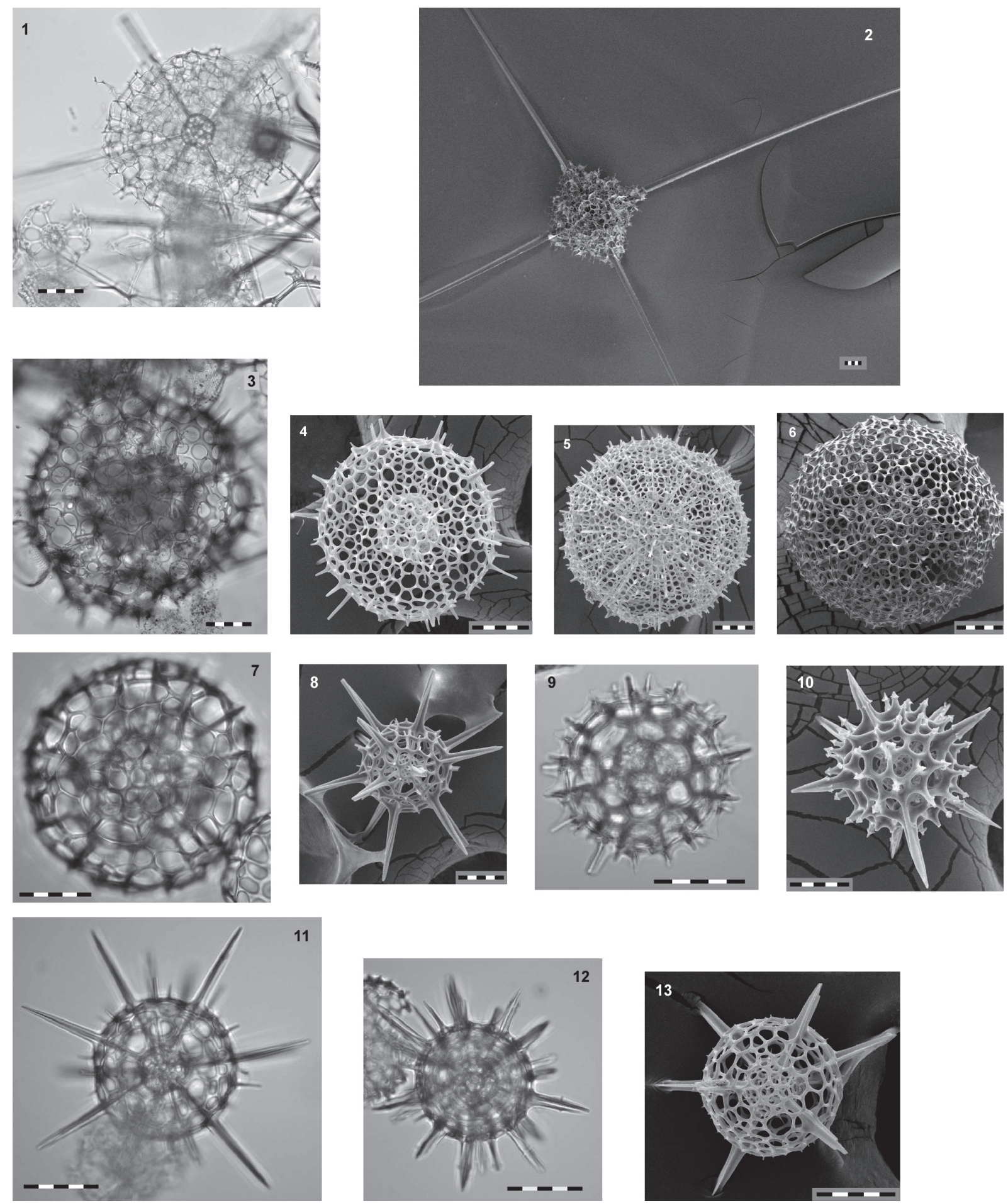

Plate 2. Spumellaria. All scale bars $=50 \mu \mathrm{m}$. Spongosphaera polycantha, 2. Spongosphaera streptacantha, 3. Actinomma antarcticum Group?, 4-5, 6? Actinomma arcadophorum, 7-13. Actinomma spp. (figs. 1, 2, 6, 7, 9, 11, 12.: M9, MC, 0-1 cm; fig.3.: M7, MC, 0-1 cm; figs. 4, 5, 8, 10, 13.: M5, MC, 0-1 cm) 
Plate 3
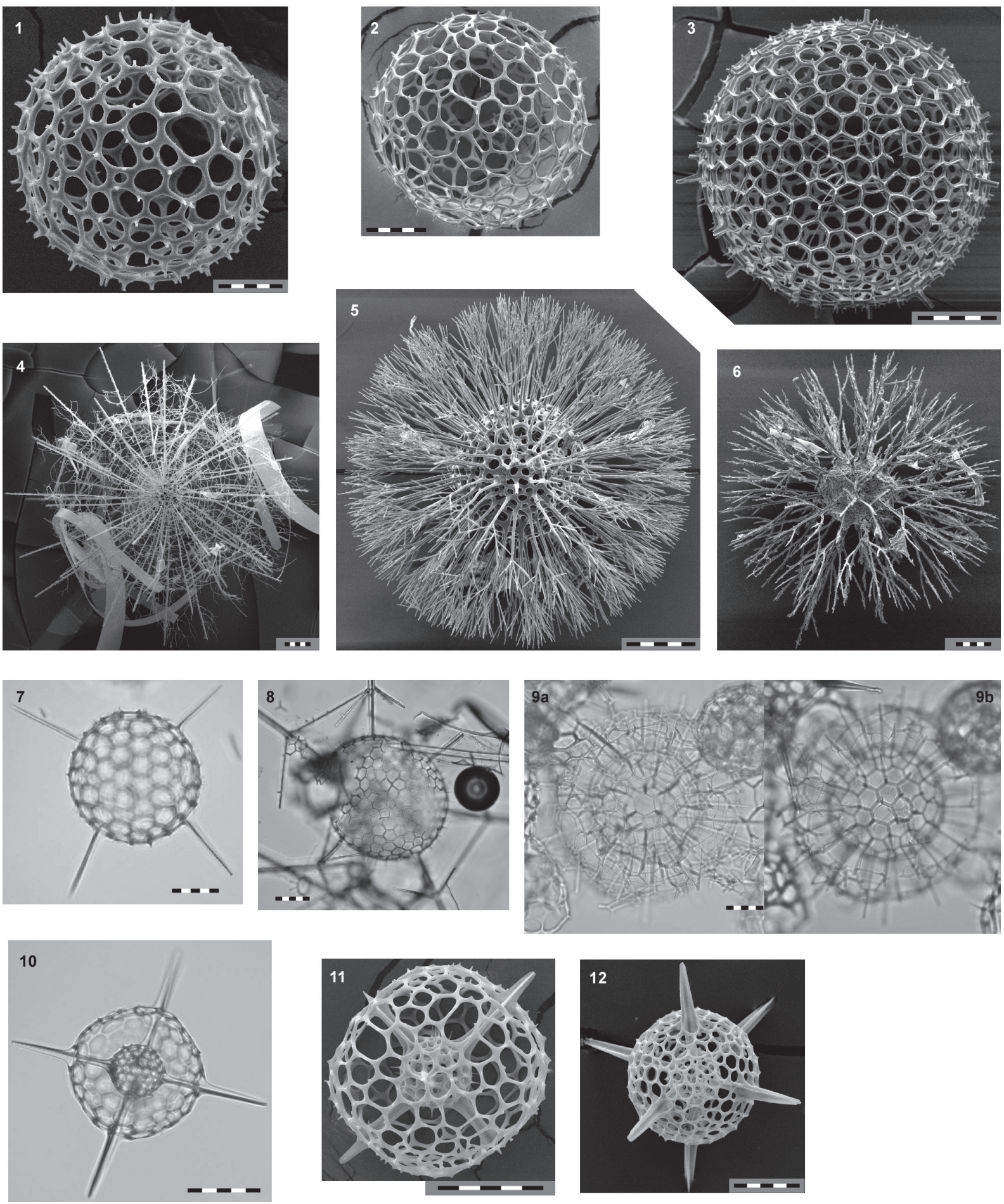

Plate 3. Spumellaria. All scale bars $=50 \mu \mathrm{m}$. 1. Acanthosphaera actinota, 2, 3. Actinoshapera spp., 4. Arachnosphaera myriacantha, 5. Cladococcus cervicornis, 6. Cladococcus scoparius, 7. Cladococcus viminalis, 8. Astrosphaera hexagonalis, 9. Drymosphaera dendrophora, 10. Hexacontium hostile, 11. Hexacontium melpomene, 12. Hexacontium spp. (figs. 1, 11.: M5, MC, 0-1cm; figs. 2, 7 , 9, 10.: M9, MC, 0-1 cm; fig. 3.: M7, MTD, 300 m; fig. 4.: M2, NORPAC net sample (NORPAC), 0-50 m; fig. 5.: M7, MTD, 300 m; fig. 6.: M7, MTD, $50 \mathrm{~m}$; fig. 8.: M7, MC, 0-1 cm). 
Plate 4
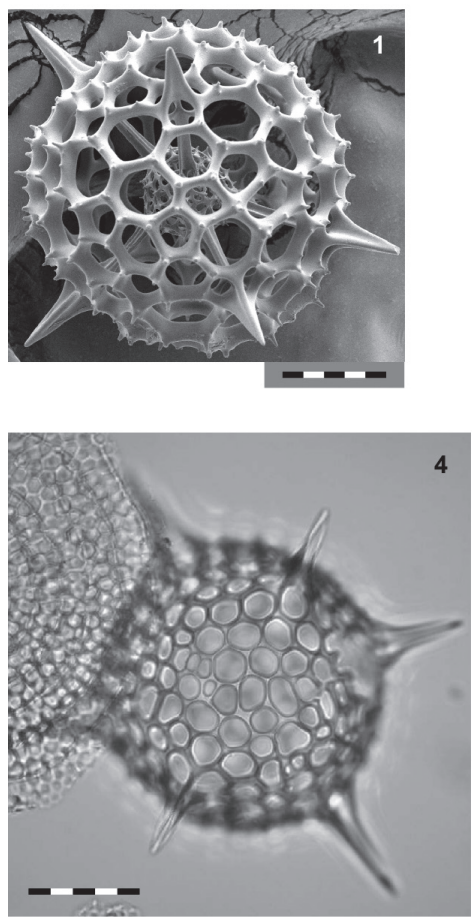
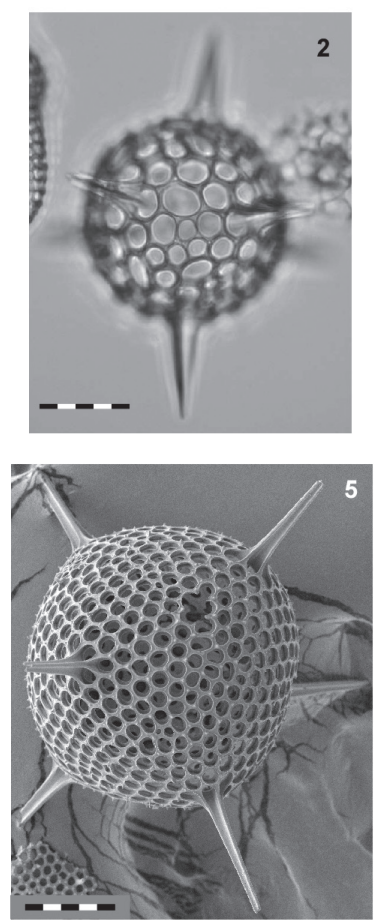

2
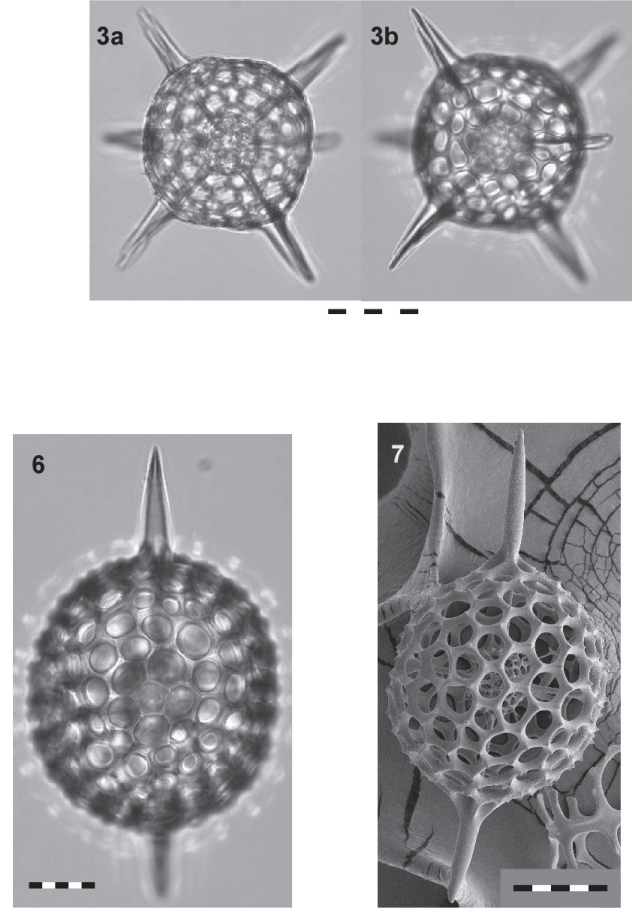
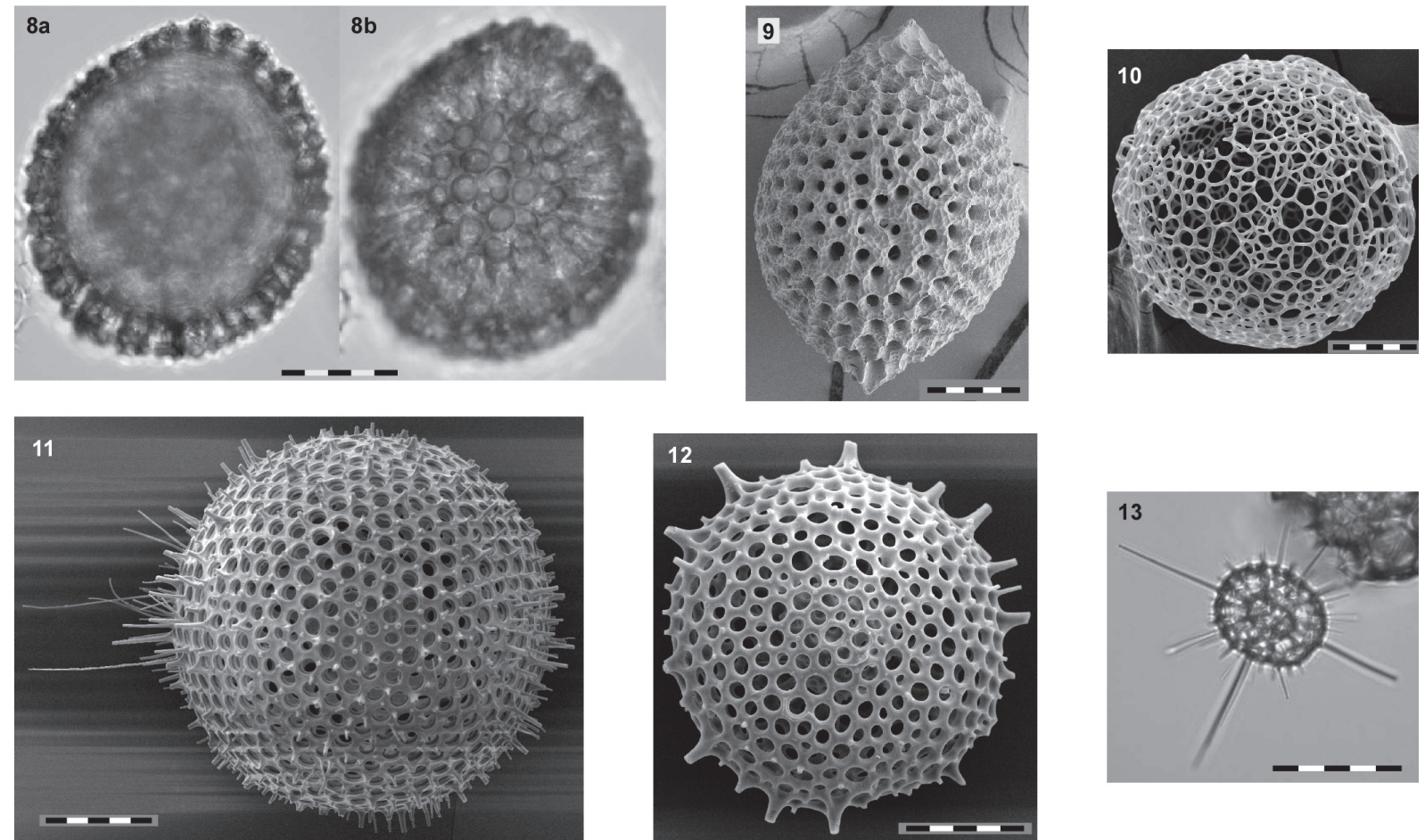

Plate 4. Spumellaria. All scale bars $=50 \mu \mathrm{m}$. 1-3. Hexacontium spp., 4, 5. Hexalonche amphisiphon, 6, 7. Axoprunum stauraxonium, 8, 9. Druppatractus sp., 10-13. Actinomiidae spp.(figs. 1-9, 13.: M9, MC, 0-1 cm; fig. 10.: M5, MC, 0-1 cm; fig. 11.: M7, MTD, 300 m; fig. 12.: M9, MTD, $750 \mathrm{~m}$ ) 
Plate 5
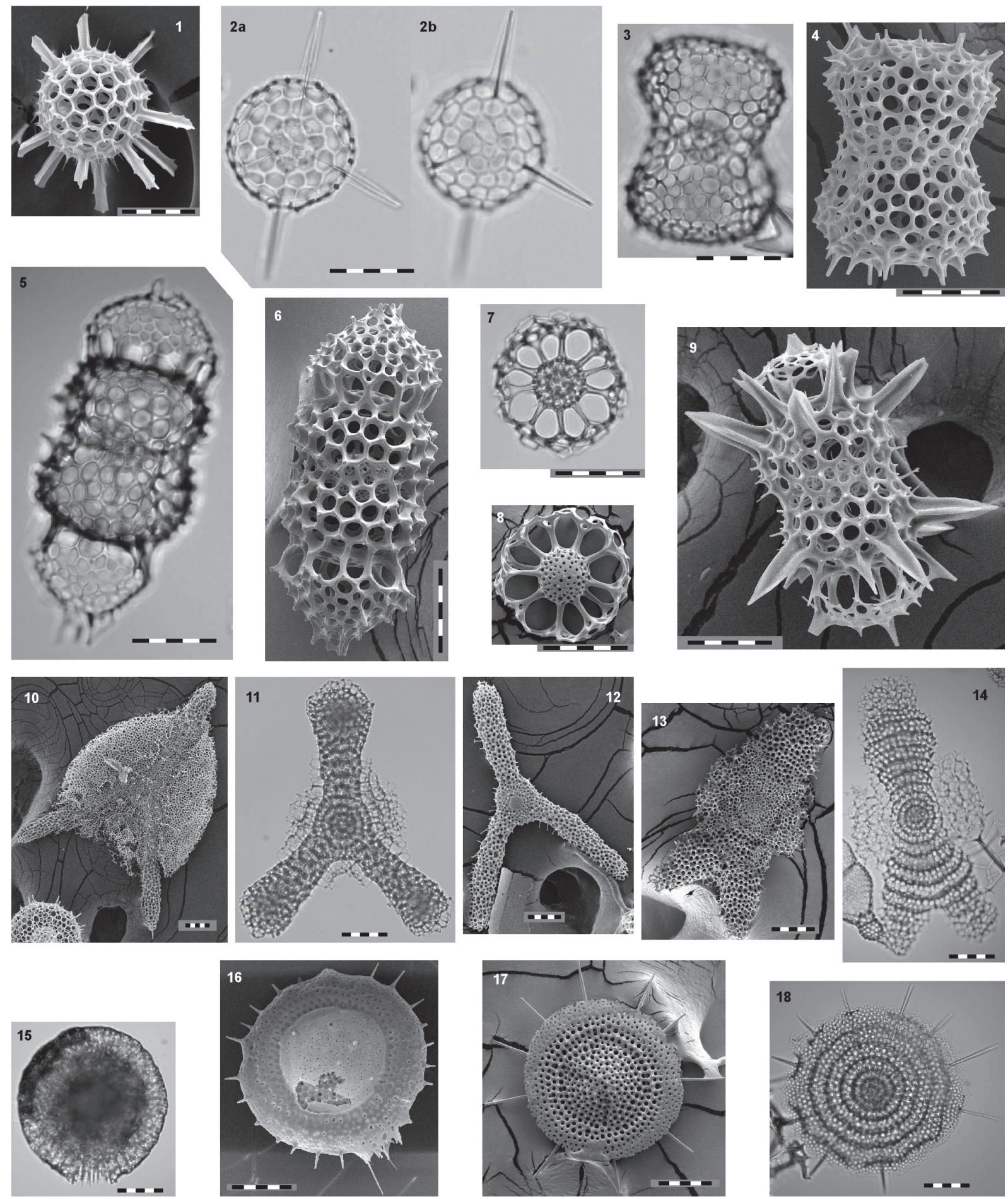

Plate 5. Spumellaria. All scale bars $=50 \mu \mathrm{m} . \mathbf{1}$, 2. Actinomiidae spp., 3-8. Didymocyrtis tetrathalamus tetrathalamus, 9. Didymocyrtis aff. tetrathalamus, 10-12. Euchitonia elegans, 13, 14. Amphirhopalum ypsilon, 15. Spongopyle osculosa, 16. Stylochlamydium venustum, 17, 18. Stylodictya asteriscus, (figs. 1, 4, 9, 10, 12.: M5, MC, 0-1 cm; figs. 2, 3. 5-8, 11, 13-15, 17, 18.: M9, MC, 0-1 cm; fig. 16.: M9, MTD, $750 \mathrm{~m}$ ) 
Plate 6
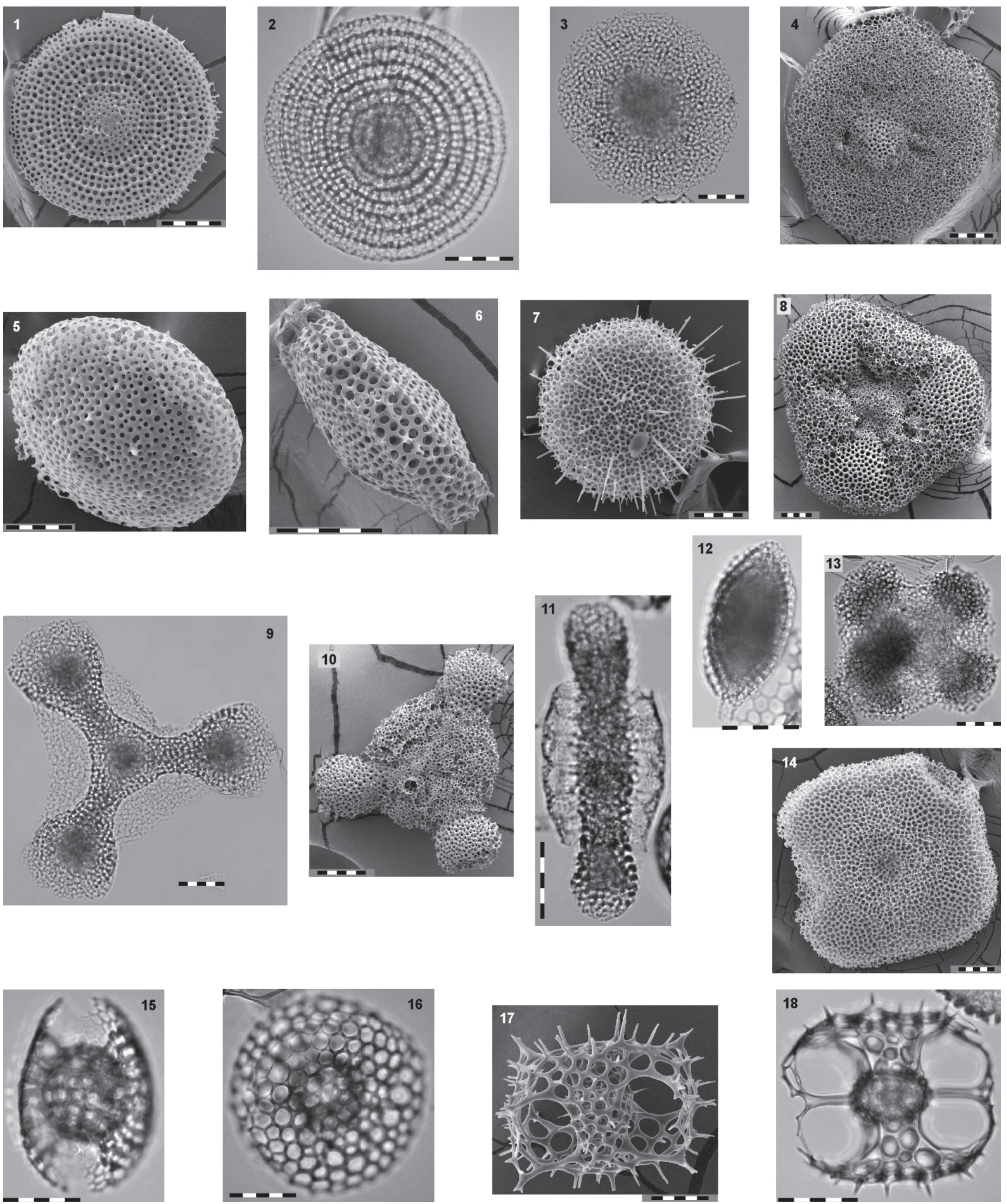

Plate 6. Spumellaria. All scale bars $=50 \mu \mathrm{m}$. 1, 2. Stylodictya validispina, 3-7. Spongodiscidae spp., 8-10. Dictyocoryne spp., 11. Spongurus cylindricus, 12. Spongurus spindalis, 13, 14. Spongaster tetras tetras, 15, 16. Heliodiscus macrococcus, $17,18$. Tetrapyple octacantha group (figs. 1, 5, 7, 14: M5, MC, 0-1 cm; figs. 2-4, 8-13, 15- 18.: M9, MC, 0-1 cm). 
Plate 7
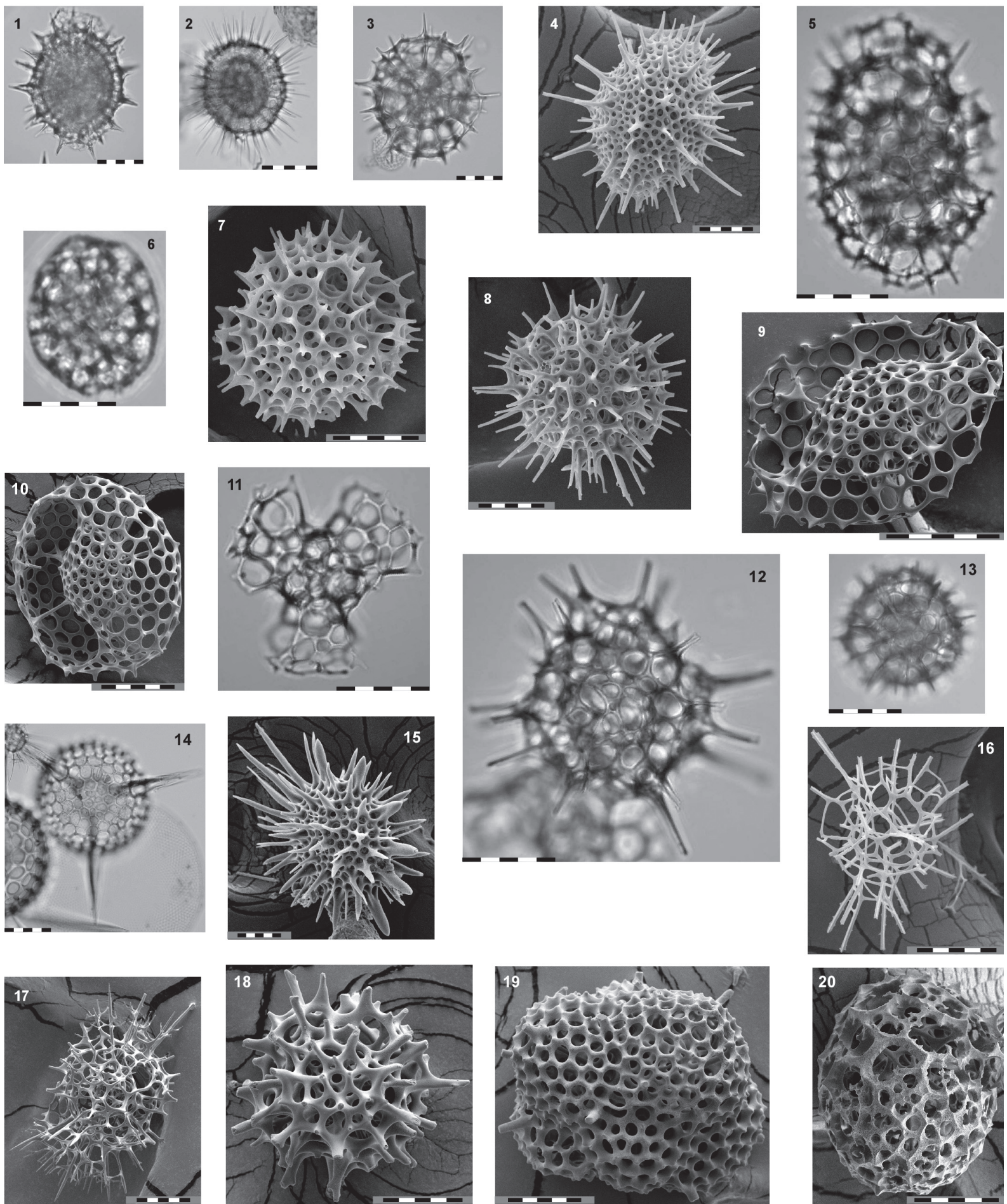

Plate 7. Spumellaria. All scale bars $=50 \mu \mathrm{m} . \mathbf{1}$, 2. Tholospira cervicornis group, 3. Tholospira? sp., 4-6. Larcopyle buetschlii, $7, \mathbf{8}$. Lithelius spp.?, 9, 10. Larcospira quadrangular, 11-20. Spumellaria spp. (figs. 1-3, 5, 6, 9-13, 17-20.: M9, MC, 0-1 cm: figs. 4, 7, 8, 15, 16.: M5, MC, 0-1 cm; fig. 14.: M7, MC, 0-1 cm) 
Plate 8
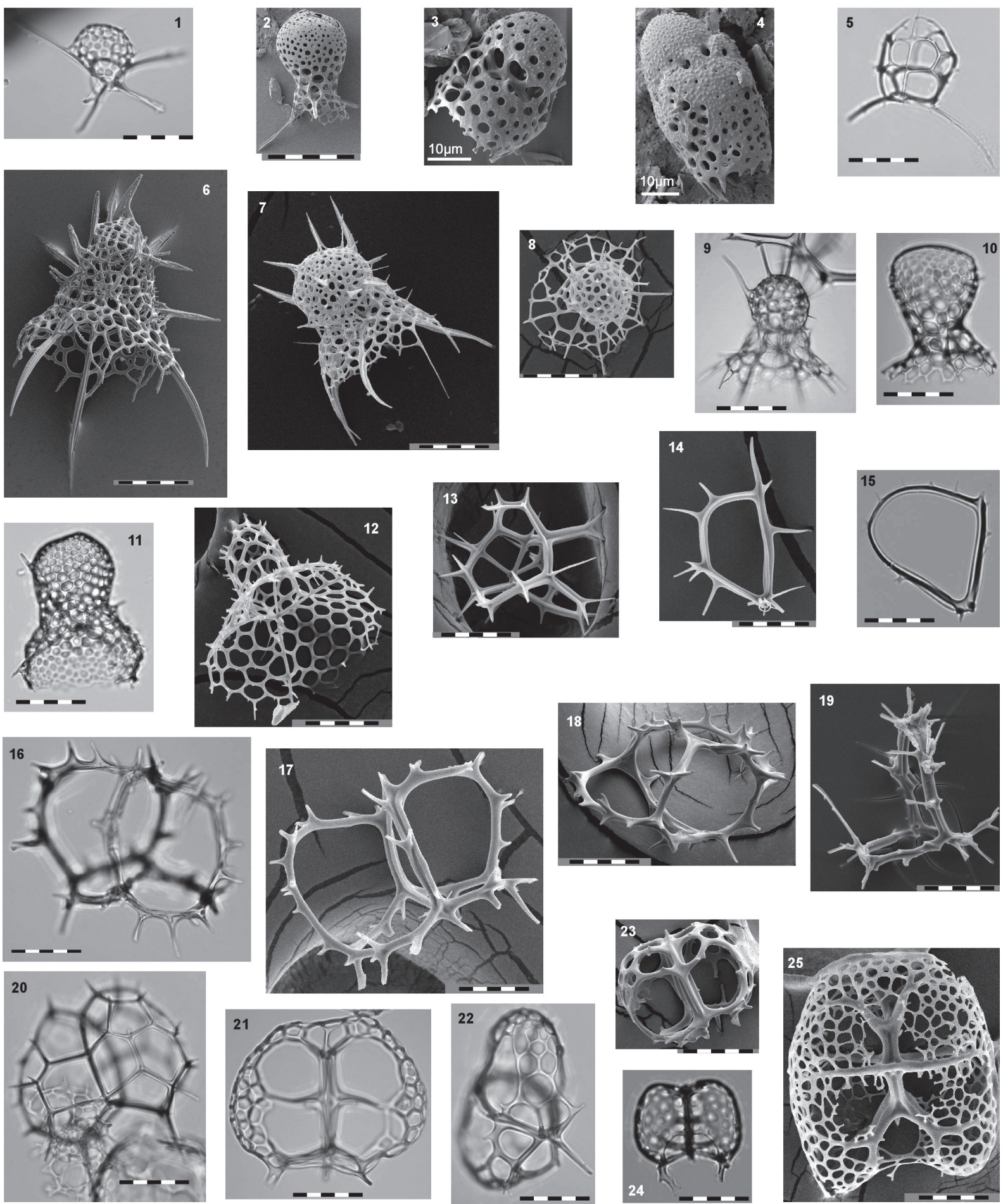

Plate 8. Nassellaria. All scale bars except for figs. 3 and $4=50 \mu \mathrm{m}$. 1. Peridium sp., 2. Peromelissa phalacra, 3, 4. Plagoniidae spp., 5. Plectacantha sp., 6. Pseudodictyophimus sp.?, 7-9. Arachnocorys umbellifera, 10-12. Lophophaena spp., 13. Pseudocubus obeliscus, 14, 15. Zygocircus productus, 16, 17. Acanthodesmia vinculata, 18, 19. Lophospyris spp., 20. Lophospyris pentagona pentagona, $21,22$. Phormospyris herdisae, 23. Ceratospyris borealis, 24. Phormospyris stabilis scaphipes, 25. Liriospyris reticulata? (figs. 1, 5, 9-11, 18, 20-24.: M9, MC, 0-1 cm; figs. 2-4, 7, 8, 12-14, 17, 25.: M5, MC, 0-1 cm; fig. 6.: M7, MTD, 300 m; fig. 19.: M9, MTD, 50 m) 
Plate 9
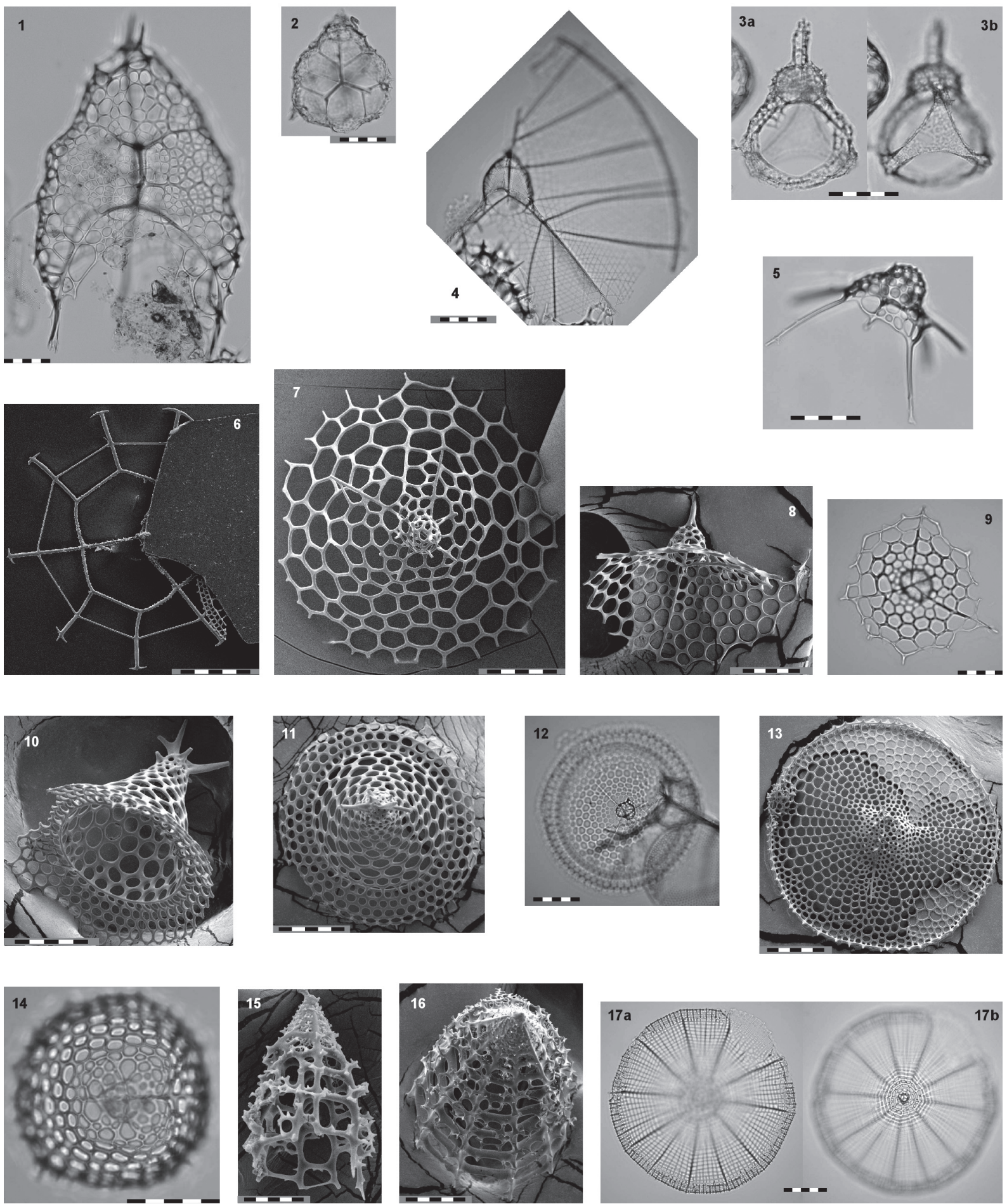

Plate 9. Nassellaria. All scale bars $=50 \mu \mathrm{m}$. 1, 2. Androspyris huxley, 3. Clathrocanium coarctatum, 4. Callimitra sp., 5. Tetraphormis rotula, 6. Tetraphormis dodecaster, 7-9. Lampromitra spp., 10, 11. Eucecryphalus cervus, 12. Eucecryphalus tricostatus (inside view), 13, 14. Eucecryphalus spp., 15, 16. Peripyramis circumtexta, 17. Lithrachnium eupilium (figs. 1, 2.: M7, MC, 0-1 cm; figs. 3-6, 8-10, 12-14, 16, 17.: M9, MC, 0-1 cm; fig. 7.: M7, MTD, $300 \mathrm{~m}$; fig. 15.: M5, MC, 0-1 cm) 
Plate 10
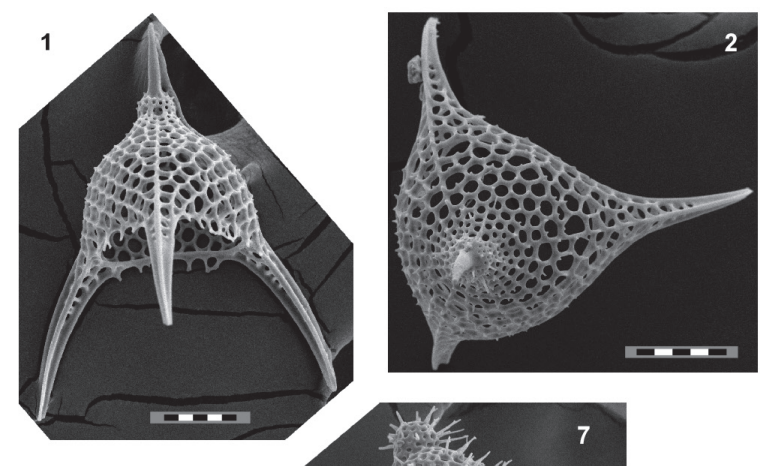

7
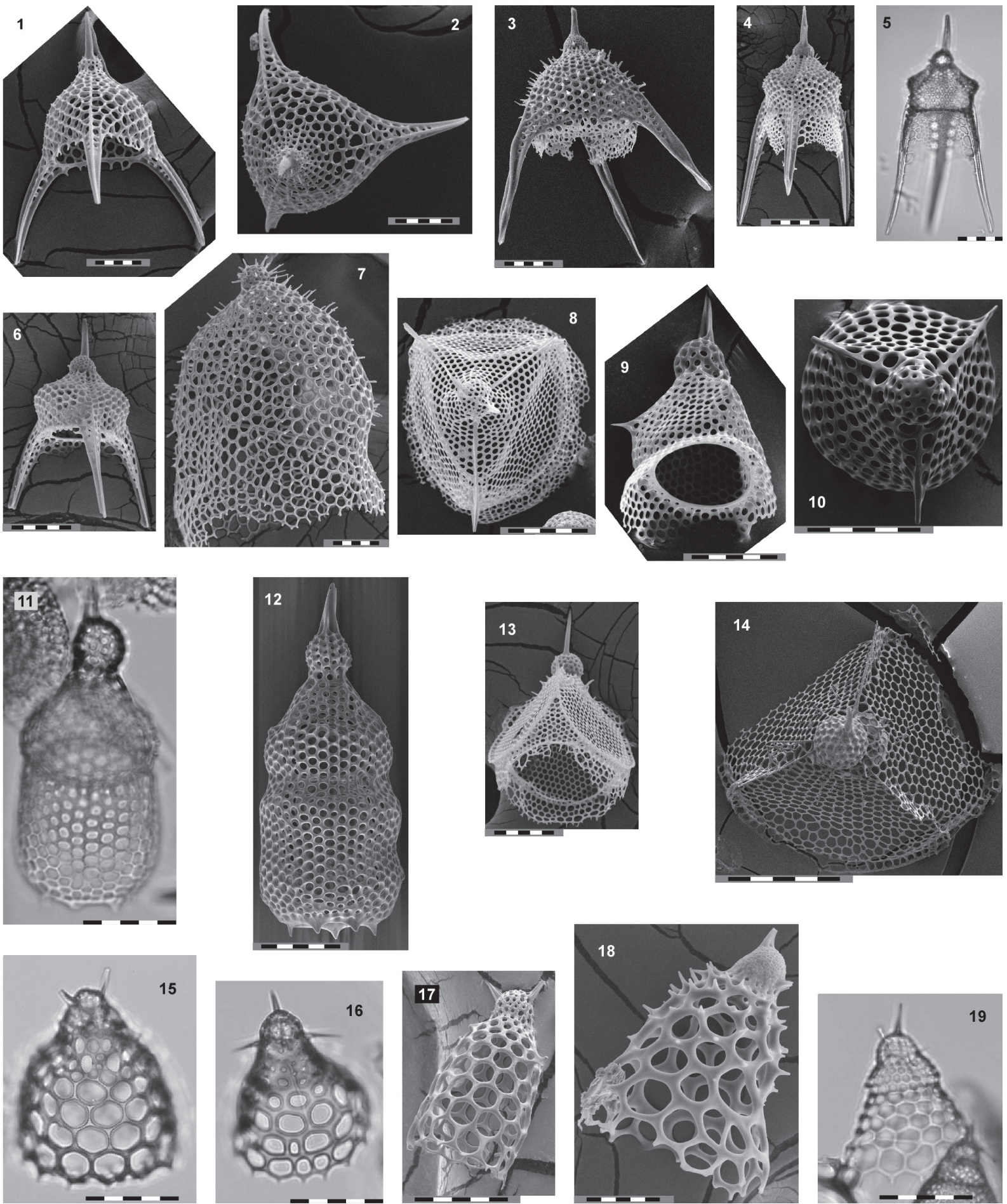

Plate 10. Nassellaria. All scale bars $=50 \mu \mathrm{m} .1$ 1, 2. Pterocanium trilobum, 3. Pterocanium praetextum eucolpum, 4-6. Pterocanium praetextum praetextum, 7. Conarachnium parabolicum, 8-10. Stichopilium bicorne, 11, 12. Theocorythium trachelium, 13. Lipmanella bombus, 14. Lipmanella sp., 15. Cycladophora bicornis, 16. Cycladophora davisiana, 17. Cycladophora cornutoides, 18. Pterocyrtidium dogieli, 19. Theoperidae sp., (figs. 1-4 , 6-9, 13, 18.: M5, MC, 0-1 cm; figs. 5, 10-12, 15-17, 19.: M9, MC, 0-1 cm; fig. 14.: M9, MTD, 50 $\mathrm{m})$. 
Plate 11
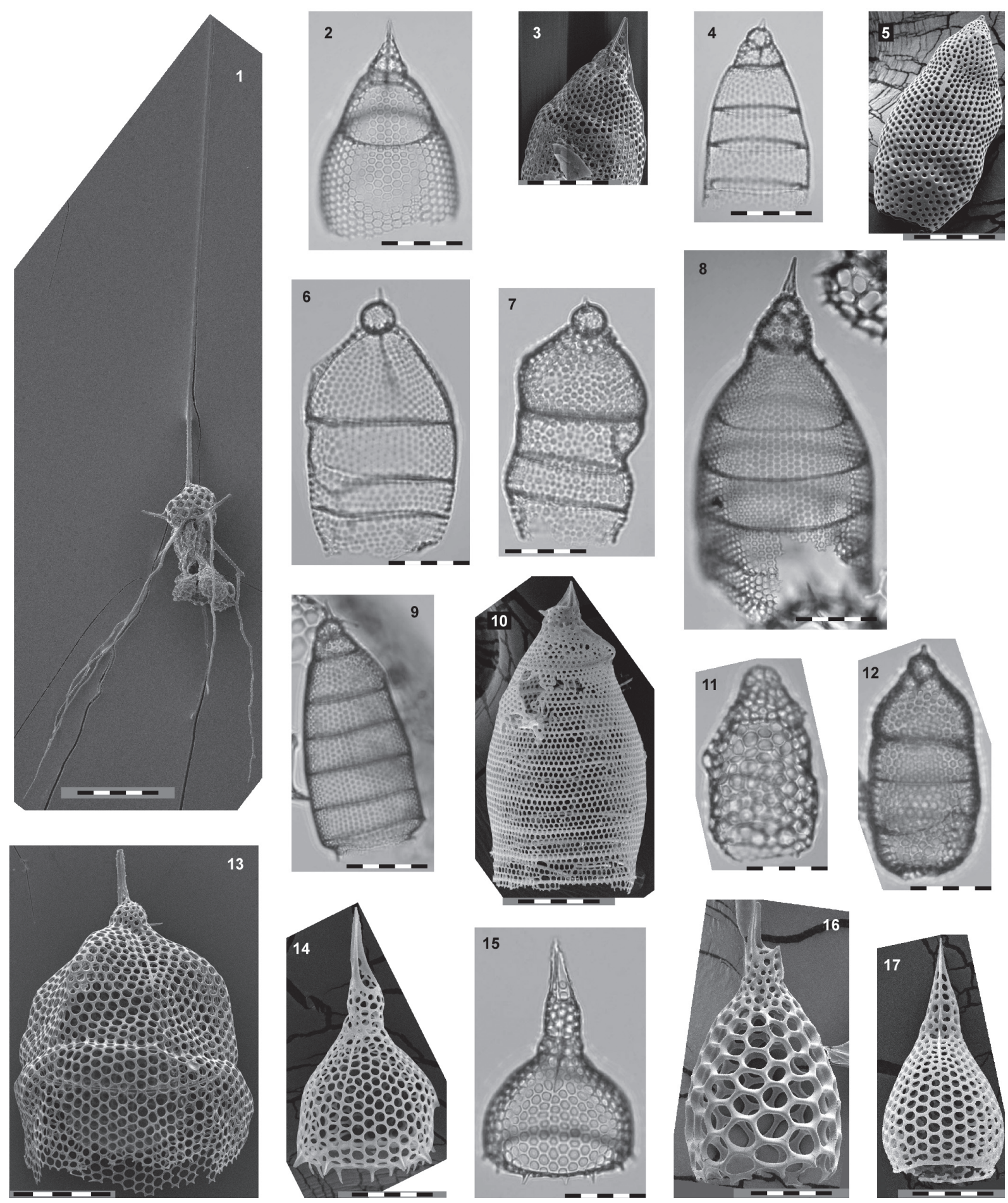

Plate 11. Nassellaria. All scale bars $=50 \mu \mathrm{m}$. 1. Tetracorethra tetracorethra, 2, 3. Pterocorys zancleus, 4, 5. Eucyrtidium acuminatum, 6, 7. Eucyrtidium anomalum, 8, 9. Eucyrtidium dictyopodium, 10. Eucyrtidium hexastichum, 11-13. Eucyrtidium spp., 14, 15. Anthocyrtidium ophirense, 16, 17. Anthocyrtidium zanguebaricum (fig. 1.: M9, MTD, 50 m; figs. 2-9, 11, 12, 15, 16.: M9, MC, 0-1 cm; figs. 10, 14, 17.: M5, MC, 0-1cm; fig. 13.: M7, MTD, $300 \mathrm{~m}$ ) 
Plate 12
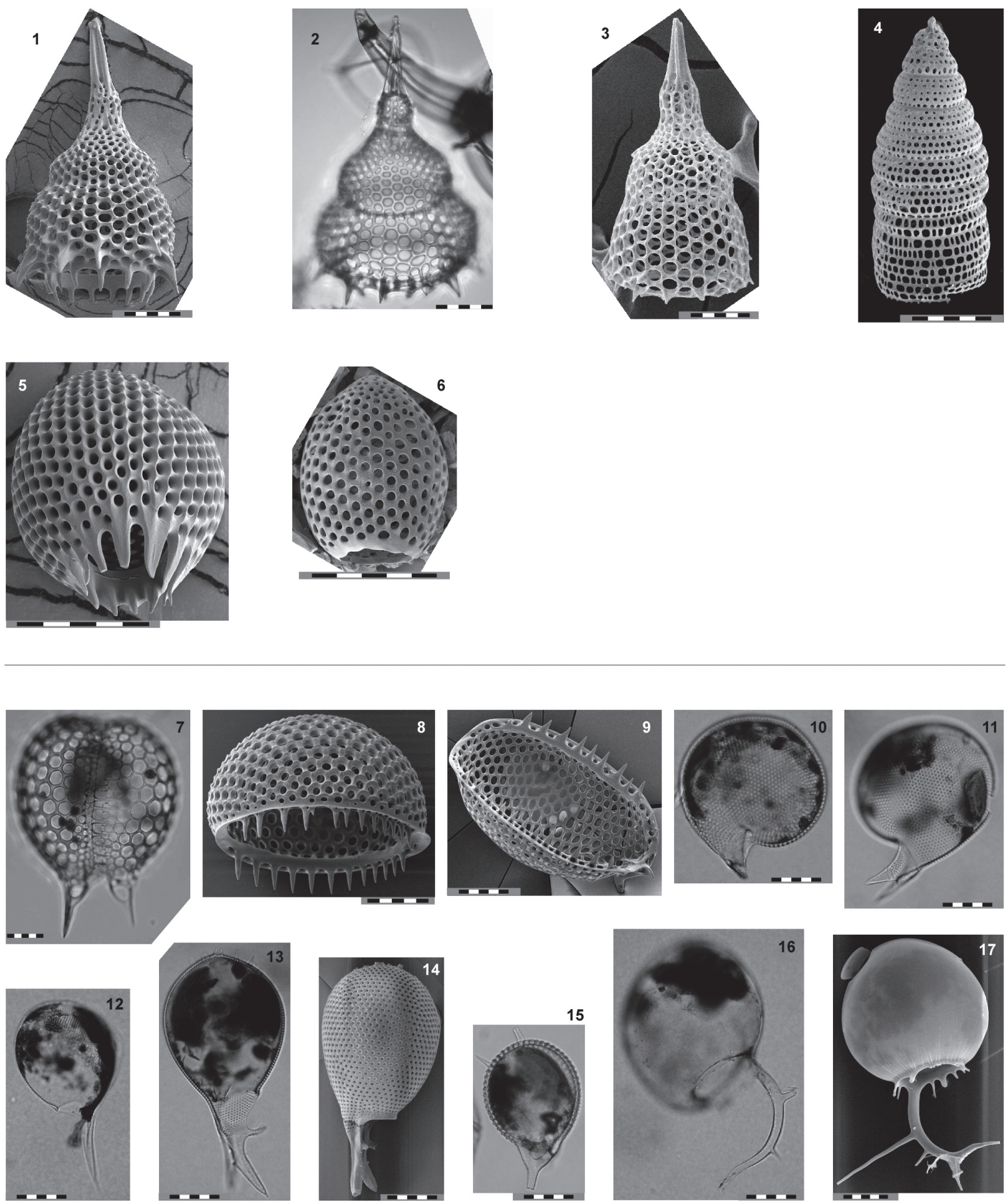

Plate 12. Nassellaria and Phaeodaria. All scale bars $=50 \mu \mathrm{m}$. 1-3. Lamprocyclas maritalis group?, 4. Botryostrobus auritus/ australis, 5, 6. Carpocanistrum spp., 7. Conchidium caudatum, 8, 9. Conchellium capsula, 10. Challengerosium? sp., 11. Protocystis auriculata, 12. Protocystis xiphodon, 13, 14. Challengeron willemoesii, 15. Challengellanium diodon?, 16, 17. Euphycetta lucani (figs. 1, 2, 5, 6.: M9, MC, 0-1 cm; figs. 3, 4.: M5, MC, 0-1 cm; fig. 7.: M9, MTD, $200 \mathrm{~m}$; figs. 8, 9.: M7, MTD, 300m; fig. 10.: M5, MTD, 300 m; figs. 11, 15.: M5, MTD, 500 m; figs. 12, 13, 16.: M5, MTD, 200 m; fig. 14.: M7, MTD, 1000 m; fig. 17.: M9, MTD, $750 \mathrm{~m})$ 
Plate 13
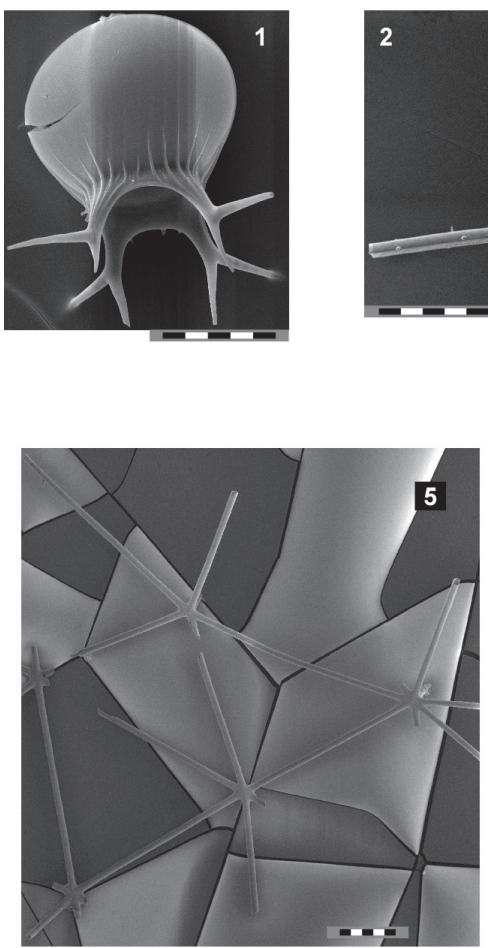

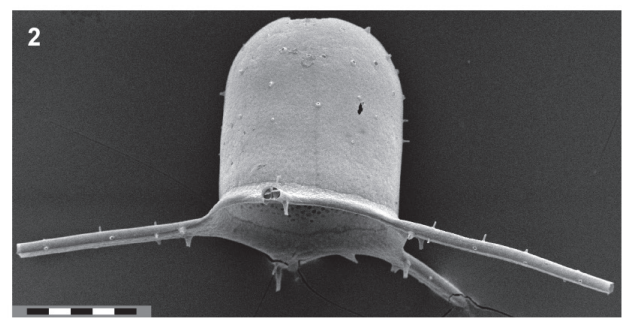

6

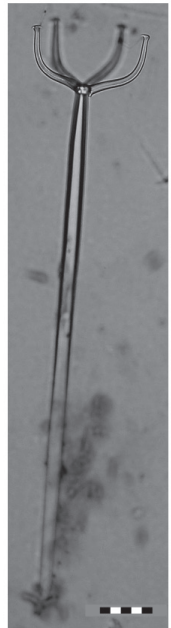

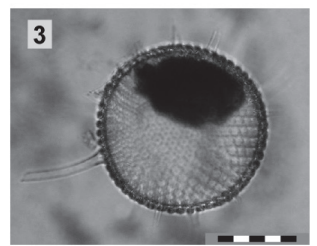
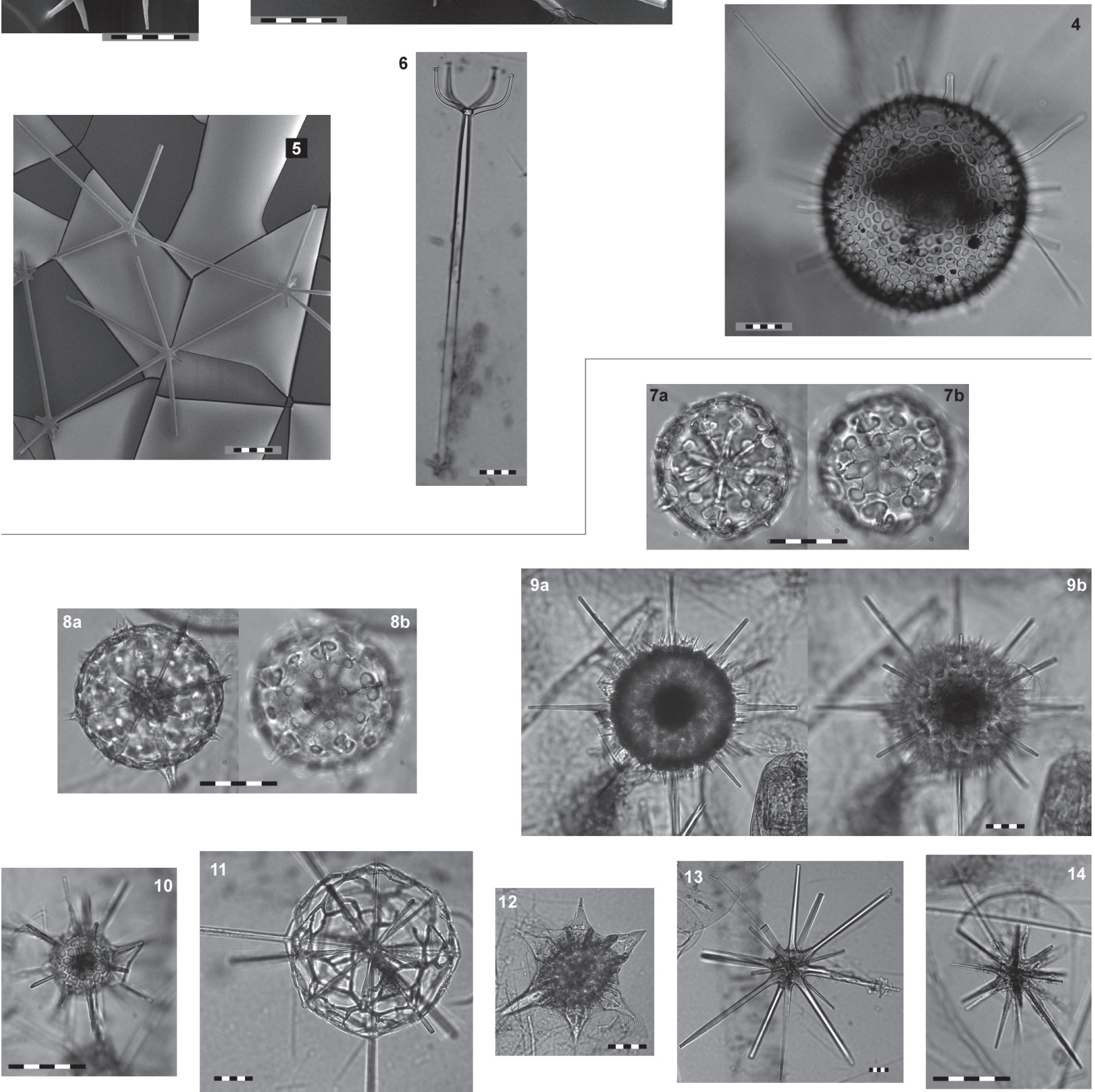

Plate 13. Phaeodaria and Acantharia. All scale bars $=50 \mu \mathrm{m}$. 1. Medusetta ansata, 2. Gazelletta cyrtonema, 3. Porospathis? sp., 4. Castanidium longispinum?, 5. Aularia ternaria, 6. Aulographis? sp., 7, 8. Acantharia sp. 1, 9, 11-14. Acantharia spp., 10. Acantharia sp. 2 , (fig. 1.: M2, NORPAC, 0-50 m; fig. 2.: M7, MTD, $50 \mathrm{~m}$; fig. 3.: M7, MTD, $750 \mathrm{~m}$; fig. 4.: M7, MTD, $100 \mathrm{~m}$; fig. 5.: M7, MTD, $300 \mathrm{~m}$; fig. 6.: M9, MTD, $750 \mathrm{~m}$; figs. 7-14.: M5, MTD, $0 \mathrm{~m}$ ) 
